Article

\title{
Perception of Environmental Spillovers Across Scale in Climate Change Adaptation Planning: The Case of Small-Scale Farmers' Irrigation Strategies, Kenya
}

\author{
Volenzo Tom Elijah * $*$ and John O. Odiyo \\ School of Environmental Sciences, Department of Hydrology and Water Resources, University of Venda, \\ Thohoyandou 0950, South Africa; john.odiyo@univen.ac.za \\ * Correspondence: volenztom@gmail.com; Tel.: +27-73-4561800
}

Received: 24 October 2019; Accepted: 9 December 2019; Published: 26 December 2019

\begin{abstract}
The failure to acknowledge and account for environmental externalities or spillovers in climate change adaptation policy, advocacy, and programming spaces exacerbate the risk of ecological degradation, and more so, the degradation of land. The use of unsuitable water sources for irrigation may increase salinisation risks. However, few if any policy assessments and research efforts have been directed at investigating how farmer perceptions mediate spillovers from the ubiquitous irrigation adaptation strategy. In this study, the cognitive failure and/or bias construct is examined and proposed as an analytical lens in research, policy, and learning and the convergence of disaster risk reduction and climate change adaptation discourses. A cross-sectional survey design and multistage stratified sampling were used to collect data from 69 households. To elicit the environmental impacts of irrigation practices, topsoil and subsoils from irrigated and non-irrigated sites were sampled and analysed using AAS (atomic absorption spectrophotometer). A generalised linear logistic weight estimation procedure was used to analyse the perception of risks while an analysis of variance (ANOVA) was used to analyse changes in exchangeable sodium percentage (ESP). The findings from small-scale farmers in Machakos and Kakamega counties, Kenya, suggest multifaceted biases and failures about the existence and importance of externalities in adaptation planning discourses. Among other dimensions, a cognitive failure which encompasses fragmented approaches among institutions for use and management of resources, inadequate policy. and information support, as well as the poor integration of actors in adaptation planning accounts for adaptation failure. The failures in such human-environment system interactions have the potential to exacerbate the existing vulnerability of farmer production systems in the long run. The findings further suggest that in absence of risk message information dissemination, education level, farming experience, and information accumulation, as integral elements to human capital, do not seem to have a significant effect on behaviour concerning the mitigation of environmental spillovers. Implicitly, reversing the inherent adaptation failures calls for system approaches that enhance coordinated adaptation planning, prioritise the proactive mitigation of slow-onset disaster risks, and broadens decision support systems such as risk information dissemination integration, into the existing adaptation policy discourses and practice.
\end{abstract}

Keywords: adaptation failure; adaptation planning; economic interests; climate change; ecosystem spillovers; policy; risk perception; transformation

\section{Introduction}

Though climate change is used as justification for environmental and livelihood interventions [1], there is a risk of adaptation failure or an inability of adaptation action to meet set objectives and/or 
generate hybrid risks, such as environmental degradation [2,3]. Accordingly, disaster risk drivers such as poor land management, unsustainable use of natural resources, and declining ecosystems have emerged as focal points in climate change action and the pursuit of sustainable development goals $[4,5]$. The growing evidence of links between climate change adaptation (CCA) and disaster risks has also seen concomitant efforts at integrating disaster risk reduction (DRR) and CCA [6], with a focus on the dialectical and/or trialectic tension between resilience, adaptation and risk management within the broader social-ecological system approach, particularly the human-environment nexus [3,7]. Analytical lenses that link climate change adaptation to other drivers of change has thus emerged as essential for effective adjustment to changing climate stimuli [8].

Comprehensive adaptation planning frameworks address policy and implementation process interlinkages or scales at local and national levels $[3,9,10]$. Implicitly it encompasses the integration of sustainable development and disaster risk management lenses [11-13], policy engagement or framing $[2,3,9,14]$, as well as changes in policies and institutional arrangements that mediate successful scaling up of CCA [1]. Risk management and robust decision making are core features that address underlying risks [15], more so responses to adaptation needs that span long time horizon [16]. Focusing on implementation phase in adaptation planning is critical as statements of intent, allocated resources, and envisioned alternatives in the form of programs, legislation and rules on their own cannot guarantee effective solutions to collective adaptation needs $[17,18]$.

Innovative lenses on deliberations about risk appraisal [18], the role of values, interests, and institutions that constrain the societal response to change and unpacking of underlying causes are some of the factors of interest in the emerging approaches to climate risk management $[11,14]$. However, in spite of the recognition of the need to integrate DRR, climate change, and sustainable development, and their successes at the conceptual level, insufficient interrogation of the underlying risks tend to bias disparate adaptation planning discourses towards business as usual (BAU) implementation trajectories that undermine the effectiveness of adaptation action $[19,20]$. Most importantly, BAU or routine adjustment to adverse impacts from climate change tend to ignore social costs which are at cross purpose with some of the tenets of sustainable development. There is an urgent need, therefore, to reorient adaptation planning frameworks to minimise the risk of adaptation failure.

Social structures mediate the exchange of knowledge and behaviour, such as the development and diffusion of adaptation technology to climate change [21]. Cognition or knowledge about risks and shared understanding could build coherence and vision into integrative frameworks, such as those that concurrently address sustainability and disaster risk reduction [11,21]. Accordingly, values, beliefs, interests, knowledge and expectations are considered integral to holistic approaches and effective adaptation [3]. However, many of the existing integrative models are constrained as they fail to recognise the centrality of individuals [11]. Additionally, current integrative models pay little attention to time-related concerns that may amplify the risk of slow-onset disasters [22].

The individual agency and wider pathways of change which portend challenges in adaptation discourses [23], are related to the complex social networks and relations in which people are embedded, commitments and understanding of social and ecological risks [7,14]. Accordingly, complementary efforts that address questions of scale, fit, and interplay in policy and governance could partly resolve such dilemmas $[24,25]$. In this article, we explore how multifaceted biases and failures with respect to the existence and importance of negative externalities constrain system integration in adaptation planning discourses.

Though integration of CCA and mitigation of associated disaster risks or ecosystem spillovers, such as salinisation risks, can be advanced through theoretical and/or conceptual multiplicity [26], convergence of CCA and DRR is constrained in agricultural production systems [7]. The constraints are related to difficulties in the integration of learning, reflectivity, and change management, as well as, lack of institutionalisation of CCA-DRR into the planning process [11,14]. More specifically, there is a paucity of knowledge in diagnostic procedures and empirical evidence that illustrate conceptual and 
theoretical convergence, as well as urgency for action [2]. Specifically, there are gaps in adaptation policy framing regarding potential mechanisms for the integration of CCA-DRR models [6]. We posit that environmental externalities have great potential to facilitate a holistic vision for the convergence and operationalisation of the often disparate CCA-DRR approaches.

Though system integration at local and global scales in sustainability discourses have emerged [7], there is still little attention paid to environmental spillovers $[27,28]$. Such limited attention to environmental spillover effects is more widespread in climate change action. In risk analysis, fast and frugal heuristics is adopted if ignoring some information does not compromise accuracy of the findings [29]. We adopt the logic and concur with Reed et al. [30] and Reid and Coleen [31] that thresholds and sustainability indicators on a limited number of parameters, such as soil health (including qualitative aspects, such as salinity levels), could be used as empirical indicators to assess the effectiveness and/or failure of adaptation strategies, such as irrigation. In particular, we adapt [32] in that temporal variation in soil salinity is an appropriate indicator in the monitoring of degradation risks and proxy for sustainability trends.

To illustrate our proposition, we assess various dimensions of cognitive failures and/or biases in autonomous adaptation pathways and how this constrain transformative adaptation discourses among small-scale farmers. Building upon the above assumptions, we employ a survey study and assessment of salinity dynamics to unpack the interplay between cognitive failure, environmental externalities and adaptation failure. The quantified changes and significance interpretation is based on FAO [33] classification of salinity risks from irrigation water.

By unpacking the poorly understood environmental spillover effects, we provide insights that complement and enhance the utility of existing transformative adaptation planning frameworks. The nested adaptation assessment model thus provides holistic lenses that address multifaceted biases at policy, research and implementation levels. The model addresses complex interplay between the climate system, the human system, as well as sustainability concerns, related policy analyses and ultimately system integration in adaptation planning. In so doing, the study contributes to the development of a robust and innovative diagnostic approach that integrates empirical data, cognitive and scale dynamics (such as, institutional polices, farmer management practices) in projecting adaptation failure.

\section{The Multifaceted Dimensions to Cognitive Construct In Adaptation Policy}

The multifaceted dimensions to cognitive failure and/or bias construct in adaptation planning discourses is presented hereunder.

\subsection{The Policy-Practice Divide as Cognitive Failure}

The development paths and the choices that define adaptation choices have greater bearing on the severity of future climate impacts, local-scale disaster risk reduction (DRR) and resource management [34], as well as broader social dimensions, such as risk perception [35]. Though planned adaptation presents new opportunities in the mitigation of climate change related risks [36], reactive or autonomous adjustments to adverse climate stimuli and the associated investments may increase the risk of maladaptation, hence an increased exposure of ecosystems, sectors, or social groups to hybrid or secondary risk $[19,37,38]$. For example, the adoption of technologies in water management such as in flood control, has potential for new downstream hazards, in itself an example of negative interactive impacts between adaptation, governance failures and disasters [39]. The environmental damage and lack of fit for purpose associated with such interactions has been termed as adaptation failure $[2,3,9]$.

Optimising the benefits and concomitant minimisation of maladaptation risks through robust adaptation, mitigation, and sustainability frameworks has emerged and been suggested as a triple win strategy in adaptation policy framing $[3,9,40,41]$. Accordingly, the effective formulation of adaptation strategies, as well as the success of CCA policy and programming in climate risk management, to a large extent, is predicated on local knowledge of adaptation [42], local context of adaptation strategies [43,44], 
as well as agent perception $[9,45,46]$. In addition, effective adaptation depends on policy support that facilitates environmental sustainability, as well livelihood capital, such as financial returns and knowledge stocks [43]. The identification of causes, agents, and flows behind the externalities or spillovers is thus critical to understanding mitigation of externalities [7,24].

Decision making is unpacked through adaptation activity and solution spaces, such as individual, technology, livelihoods, behaviour, the environment, institutions, popular, and policy discourses [1]. Enhancing better understanding and managing effects across multiple systems and scales is thus critical in sustainability policy and management. In particular, the use of human perception lenses has immense potential in promoting system resilience [7,47]. However, individual adaptation hinges on whether an impact, anticipated or experienced, is perceived as a risk and whether it should and/or is acted upon through adaptation policies, or is constrained by inertia and cultures of risk denial [21]. This necessitates the use of holistic approaches that consider feedback loops to shape outcomes from the complex interplay between the climate system, the human system and ecosystems, as well as an assessment of sustainability $[2,7,9,48]$.

The multiple interactions between governance and resource users' systems are consequential on provision of ecosystem goods and services, as well as, externalities [24]. Accordingly, under the sustainable development paradigm, ecological considerations are prioritised over short-term economic pay-offs [49]. In situations of inadequate information, and where alternatives and consequences are not well understood, the polluter pay and the precautionary principle [50] are widely accepted as complimentary to legislative and enforcement mechanisms [50,51]. However, for most developing nations, the precautionary and polluter pay principle have been adjudged to be ineffective in the mitigation of environmental externalities [2,52]. The pursuit of sustainability has thus been re-oriented to encompass coordination mechanisms and integrative use of social ecological lenses that unpack the complex interplays between agent cognition, governance, social and policy discourses with regard to outcomes, such as environmental externalities [7,24]. In essence, synergies and trade-offs between broader development goals and climate-risk management are the focus in adaptation planning [2,53]. However, environmental spillovers or downstream costs, such as salinisation, have received little attention in such discourses.

Though agent behaviour across scale, the processes in behaviour development, as well as behaviour patterns can be exploited in scenario building of likely spillover impacts [54], there is lack of understanding and concern for important linkages between natural resource management, development, DRR and climate change mitigation and adaptation constrain systemised planning [19,55]. For instance, policy makers, depending upon their institutional mandates, may view a single hazard, such as waterborne diseases and flooding, separately, instead of multiple, interrelated hazards at one time $[9,39]$, as well as demonstrate a bias to immediate adaptation needs during policy framing and decision making [14].

Reducing the risk of adaptation failure depends on the extent to which multiple actors across scale and the broader social contexts are integrated into decision making $[2,14,19,56,57]$, as well as responsive legislative frameworks [56]. Information and policy coherence [9] as well as the coordinated framing of the problem among actors with influence on adaptation planning and policy tend to substantially reduce such risks $[19,57]$. Policy and information support frameworks have great potential to guide informed decision making and a paradigm shift towards effective adaptation action in general, as well as learning about, and mitigation of negative social and environmental externalities in particular [9].

Though adaptation-mitigation-sustainability frameworks exist, accounting for environmental spillovers in planning processes remains as a challenge [7]. Such a challenge is routinely encountered in search of solutions to environmental change problems with intractable feedback loops [58]. By default, the favoured technology end state solution approaches in routine adaptation discourses fail to acknowledge and account for environmental footprints $[59,60]$. As adaptation and mitigation in agriculture are country and farmer specific and by farmer characteristics, such as farm size and education level [61], risk reduction planning process involves a diverse solution space, such as, 
knowledge of situations (cognition), processes and systems $[3,5,11,14]$. The low institutional awareness and institutional coordination between agencies responsible for disaster management and climate change adaptation, as well as overall development planning thus tend to entrench the reactive and/or fragmented adaptation solutions [6,12].The divergence is reflective of cultural cognitive institutions that affect system understanding, boundary setting and participatory search for solutions $[2,11]$. This may result into biased planning frameworks and adaptation failure $[17,39,62]$. Implicitly holistic approaches that pay attention to feedback loops between the climate system and the human system are invaluable in adaptation planning [48]. In particular, multi-hazard and multisectoral frameworks that foster people centered, collaborative partnerships, mechanisms and institutions for implementation of instruments relevant to building resilient socio-ecological systems are critical.

\subsection{Cognitive Failure and Mitigation of Ecosystem Risks}

Though the three domains of adaptation, mitigation and productivity are dialectically related to the other two and thus intricately intertwined [63], operationalising system convergence is undermined by absence of over-arching national policies that integrate CCA and DRR into various aspects of land-use planning and typified by lack of capacity to assess, interpret and apply data on climate change risks and vulnerabilities. Convergence is also undermined by bottlenecks in the integration of plans among and within agencies [12]. The dissonance between individual values and formalised institutions and organisations as entry points for alternative adaptation pathways [23], and convergence between CCA and DRR is thus likely to demand substantial institutional changes [6].

Knowledge of consequences, their causes, and implications play a role in peoples risk belief and mitigation actions [64]. Cognition or perception aid in mobilising peoples' commitment to action over environmental problems [65]. Perception of risk, habit, social status, and age as individual attributes are thus critical in collective action decision-making [21]. At the community level, analytical and conceptual lenses that unbundle cognitive biases and failures, as well as integrate and transform individual and collective agency, are critical to risk reduction and resilience building [66]. Theoretical and empirical multiplicity lenses improve analytical rigour, address conceptual and knowledge gaps, and solve complex problems and contextual dilemmas while encouraging synergies [26,58]. The utility of communication in CCA-DRR convergence discourses at different instutional scales $[6,67]$, as well as development and dissemination of adaptation technology options [68], is thus critical.

The increase in risk and vulnerability from climate extremes calls for increased attention to an array of underlying drivers and lenses, such as, ecosystem services, governance and information needs [24]. However the dilemma arises due to divergence in priorities at different times and scales hence the need for analytical and policy innovations that advance and/or broker complementarity in CCA policy, advocacy and programming spaces [1,67]. However, the complex human-environment system feedbacks are potential dilemmas that may constrain planning. For example, though awareness plays a critical role in disaster mitigation [64], increased information may be ineffective as a tool for better decision making where profit motive (proxy for risk disposition) prevails [69]. Intuitively there is a need for innovative lenses that resolve inherent value conflicts around immediate private gain and long-term social concerns.

Though changes in external stimuli, such as temperature and moisture are sources of risks that trigger development of robust adaptation strategies at micro i.e., individual farm level [70], the farmer as a primary actor in adaptation planning, is motivated by short-term reactive incremental adaptation preferences that are biased towards immediate economic interests and/or survival objectives other than long-term sustainable risk reduction initiatives $[9,46,71]$. The prioritisation of narrow economic interests and immediate payoffs as opposed to long term social good, discounts the importance of future risks and undermine sustainability of ecosystems [1,72].

Though collective action and public support is a necessary condition for the effectiveness of mitigatory action (i.e., internalisation of environmental effects, such as methane emissions, salinity spillovers etc.), the accruing benefits from such action, are felt after long time lags and 
spread or diffused to the wider social system. The extra costs in internalising the spillovers reduces incentives for individual actor action [46,73]. The rationale seems to account for popularity of adaptation pathways that do not address negative ecosystem externalities or spillovers. In essence, effective adaptation planning, moreover the mitigation of slow onset disaster risks, should consider the integration of short term and long-term social interests.

In climate change adaptation, sustainability is often framed as a one way driver of change in the system of interest with little attention to feedbacks between the system of interest and other systems $[7,19,74,75]$, as well as poor cognition of spillover systems [76]. The cognitive barriers are linked to poor quality and/or lack of specific information, poor coordination across scale [9], fragmented understanding among the actors [2,77], as well as operational challenges among constrained agents [3]. Cognitive failure and/barriers thus inhibit informed and sustained action [78]. The failure is exacerbated by ineffective implementation and/or poor enforcement mechanisms [2,9], especially the mismatch between expert and lay perceptions of risk [79]. More importantly, most policy framings in CCA fail to consider externalities by favouring short term political needs $[14,39,80]$.

The bias towards immediate payoffs across scale increases the need for integration and use of perception at community level in the design, analysis and policy reframing on adaptation planning $[1,11,14]$. Dissemination of information on such risks or risk communication, has been found to play a critical role in the abatement of externalities [81]. The framing of communication regarding the mitigation of future risks is thus critical as it affects cognition and disaster risk reduction responses [65,82]. In particular, variation in perception is an important consideration because differences between lay and expert perceptions of risk impact the success of risk communication [79]. Investigating farmer perceptions could provide novel insights and advances in the concomitant integration of sustainability, disaster risk reduction, resilience building and development planning lenses into transformative adaptation discourses, the identification of governance gaps and betterment of system integration frameworks.

\subsection{Underlying Risks and Transformative Adaptation}

The extent to which underlying risks are addressed defines whether the adaptation pathway is transformative or incremental. Several pathways such as transformation, vulnerability reduction, disaster prevention, preparedness, response and recovery, and building resilience provide solution spaces for risk management and adaptation to extreme climate changes [83]. While incremental adaptation relies on BAU trajectories, transformative adaptation considers alternative development priorities, preferences and pathways that address the social drivers and processes. It thus incorporates early warning systems as disaster risk reduction tools and lens into planning processes $[1,2,9,14]$. Implicitly, transformative adaptation includes monitoring, evaluation and learning for improvement and policy support [9]. Operationalising transformative adaptation has however received less attention in practice $[14,81]$.

Incremental adaptation discourses primarily focus on technical approaches to improve predictive capabilities in adaptation planning cycle $[2,9,14]$. Incremental adaptation frameworks are thus short of social lenses that can unpack underlying risks. In contrast, transformative adaptation frameworks address deep rooted causes of risk and vulnerability with the primary objective being to enhance co-benefits and minimise the risk of the adaptation deficit or failure $[14,84]$. Enabling drivers towards transformative discourses include the upstream dialogue and exploration of values and visions about future decision making processes [85]. Increased awareness on the less acknowledged salinisation risks could aid such forward looking planning.

The scaling up of adaptation could provide multiple co-benefits where public participation, awareness raising campaigns, law enforcement, as well as strong political exist [86]. Improved access to information about appropriate adaptation strategies appear to support adaptation processes and resilience building at the local level [11,44], as well as raise procedural questions for decision-makers [1]. Accordingly, engagement with individuals might be a useful lens through which communities and 
practitioners are sensitised to risks with a positive impact on the construction of a more dialectical approach to DRM/CCA and sustainable development [14]. We argue that transformation pathways should revolve around the multifaceted cognitive failure construct and environmental externalities.

Though media can be exploited to enhance the understanding of disasters, especially where vicarious experience is concerned [87], some authors [88] have found no relationship between exposure to sources of information or self-rated knowledge about climate change and support for climate change policy. Such a dilemma could be resolved partly through participatory communication [89] and the concomitant use of seamless support systems, such as, risk communication, which have great potential to address cognitive biases and/or failures [81].

\subsection{Salinity Footprints and Adaptation Failure}

Water quality and its suitability for use in irrigation is judged on potential severity of problems that can be expected to develop during its long term use $[33,90]$. The total concentration of soluble salts (salinity hazard) in terms of electro-conductivity (EC), relative proportion of sodium to other principal cations (sodium hazard) expressed as sodium adsorption ratio (SAR), bicarbonate concentration relative to the concentration of calcium plus magnesium and boron hazards, or the concentration of boron or other toxic elements are the most important determinants of quality and suitability of water for irrigation [90].

Salinity is recognised as one of the greatest land degradation processes and declines in soil productivity, especially in arid and semi-arid regions [91,92]. High levels of salts in water used for irrigation has been implicated to affect soil fertility and crop yield [93]. Salinity hazards or EC exceeding certain threshold levels reduce water availability in the root zone and cause $8-86 \%$ drop in crop yields [33]. Such risks increase with use of ground water (e.g., from boreholes) of high salt content for irrigation [94]. In particular, salinity negatively alters soil microbial and biochemical properties, metabolic efficiency and growth of soil microbes [95]. Though salinity in soils tend to vary significantly, it indirectly impacts climate change through oxide $\left(\mathrm{N}_{2} \mathrm{O}\right)$ emissions, and hence has an effect on global warming [96].

While primary salinisation is associated with parent material mineralogy, secondary salinisation is dependent on agronomic practices, such as fertilization, poor drainage and use of inappropriate water sources [32,97]. In a study of groundwater quality in the Soutpansberg fractured aquifers, South Africa, agricultural activities produced localised impacts in terms of elevated concentrations of calcium, chloride, magnesium and nitrates in groundwater [98]. Where small scale production systems dominate, the underestimation of cumulative impacts of the seemingly minor individual footprints may result in an ecological disaster in the long run.

Land degradation is one of the slow onset disasters with adverse social and ecological impacts [99]. For example, in India, one of the countries where land degradation is widespread, six million hectares of the 147 million hectares of land classified as degraded is attributed to salinisation [100]. Though slow-onset disasters, such as land degradation generally do not result in sudden fatalities or casualties and acute property damage, they are more extensive in their impact and more destructive in the long term than rapid-onset disasters such as floods, hurricanes, and earthquakes [101]. Since individuals may not recognize land degradation as an underlying cause of vulnerability, awareness of such a type of a disaster is critical [102]. A lack of and/or poor knowledge of the consequences of the effect of such slow-onset disasters, such as those associated with spillovers from salinisation, fits the narrative of adaptation failure and demonstrates the intractable challenges between adaptation action and vulnerability to induced risks or spillover effects.

\subsection{The Agricultural Sector, Climate Change Risk and Adaptation Policy Context In Kenya}

Kenya is predominantly an agrobased economy where small scale farmers dominate with about $75 \%$ of the populations' livelihoods directly linked to agriculture [103]. Agriculture is thus key to overall national development, equity objectives and sustainable growth. Intuitively, weather-related 
disasters, particularly droughts, present a major challenge to the predominant rainfed agricultural production system with profound adverse impact on the economy. The adverse effects negatively affect foreign exchange earnings, food security and nutrition, employment and rural livelihoods. Adaptation to extreme weather impacts is thus a priority under National Adaptation Policy Action plans (NAPAs). Among other objectives, NAPAs envisages improved crop productivity through irrigation [104].

Adaptation to climate-related risks is expected to be achieved within a number of institutional and governance frameworks, such as the climate change Act and the Environmental Management Coordination Act (EMCA) which directly or indirectly impinges on agricultural sector planning. EMCA is a framework legislation under the stewardship of the National Environment Management Authority (NEMA), the government agency for coordination, enforcement and compliance on all matters on environment. As the principle instrument that establishes the legal and institutional framework for all matters that touches on environmental management in Kenya [105], EMCA adopts the "precautionary principle" as a sustainability safeguard in decision making. The 1st Schedule of the EMCA act, parts vi and vii provides for the process and projects that should undertake environmental impact assessments (EIA), audit (EA), and monitoring respectively. Irrigation is among projects that should undertake EIA/EA. However, the act only refers to effluents and not the processes nor the slow onset disaster risks, such as salinisation.

Building farmer resilience to climate change risks is the main objective under the Agricultural Sector Transformation and Growth Strategy [103], which in agriculture operationalises the climate change act. Though the Climate Change Act [106], broadly addresses mechanisms and measures towards low carbon climate development, it fails to address environmental externalities, such as salinity footprints, an ubiquitous adaptation pathway in the country. The Agricultural Sector Transformation and Growth Strategy envisages an increase in access to irrigation by small scale farmers from the current level of $5 \%$ to $11 \%$.

\section{Methodology}

\subsection{Study Area}

The location of study sites, Likuyani subcounty in Kakamega County and Mavoko subcounty in Machakos county respectively is provided in Figure 1. Though the study sites are located in contrasting ecological zones, both are highly populated and characterised by high poverty levels. High population and poverty levels are drivers of increased livelihood vulnerability to climate change related risks. Kakamega covers an area of $3051 \mathrm{~km}^{2}$ with a population of 1,660,651(approximated growth rate of $2 \%$ ), that translates to population density of $544.3 / \mathrm{Km}^{2}$. Machakos covers an area of $6208 \mathrm{~km}^{2}$ with a population of $1,098,584$ persons (projected growth rate approximated at $1 \%$ ), and a density of $177.0 / \mathrm{Km}^{2}$ [107].

Kakamega county is located in Western Kenya between longitude $34^{0} 35^{1} \mathrm{E}$ and latitude $0^{0}$ and $0^{0} 15^{1} \mathrm{~N}$ [108]. The county is characterized by commercial sugarcane farming as well as maize production at subsistence and commercial level as major economic activities [107]. Agriculture employs $80 \%$ of the population and is critical to poverty (currently at about $50 \%$ ) reduction in the county [109]. The Agro ecological zones (AEZs) range from UM1 (upper middle-1) to LM-3 (lower middle-3) hence variation in rainfall, agricultural potential and productivity in terms of livestock type, crop varieties and actual/potential yield levels [108]. Most of the soils in the county are thus heavily leached due to high rainfall and relay cropping. An agro-ecological zone describes agronomic conditions on basis of landform, soil types, rainfall, temperature and water availability, which in turn influences the type vegetation, length of crop growing period and their adaptability to the locality [110]. The county receives 1200-2200 mm of rainfall per annum with the first rains of 500-1100 $\mathrm{mm}$ and second rains of $450-850 \mathrm{~mm}$. However, farmers in the area, notably the northern part (the study site), is affected by extreme climate change extremes in form of droughts. The extreme weather episodes are exacerbated by high evapo-transpiration that averages 1600 to $1800 \mathrm{~mm}$. Generally, the county has experienced 
warming trends, interannual variability in the amounts of rainfall evidenced through increased number of consecutive dry days, as well as intense downpours that occasion flooding [109].

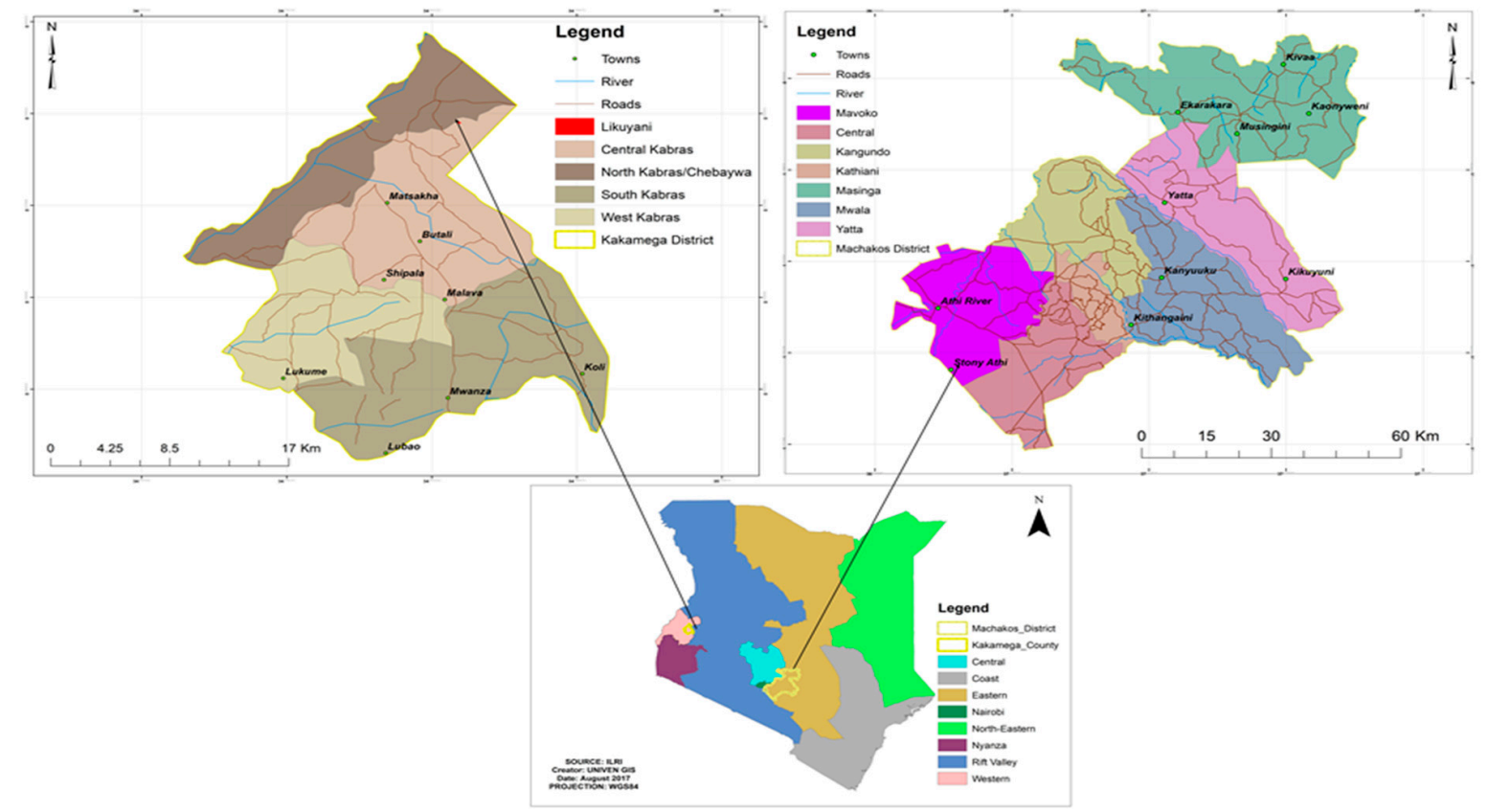

Figure 1. Geographical Information System (GIS) Generated map of study sites in Kakamega and Machakos Counties, Kenya.

Machakos county is located in Eastern Kenya, between latitudes $0^{\circ} 45^{\prime}$ and $1^{\circ} 31^{\prime} \mathrm{S}$ and longitudes $36^{\circ} 45^{\prime}$ and $37^{\circ} 45^{\prime} \mathrm{E}$ and an elevation of between 790 and $1594 \mathrm{~m}$ above sea level. The agriculture economy in the county contributes $70 \%$ of household income and is characterized by livestock farming, as well as small-scale crop production at subsistence and commercial levels [107]. The AEZ range from LM2 (lower middle-1) to LM-3 (lower middle-3). The county is characterised by a semi-arid type of climate (except in highland areas) and cool to hot temperatures that averages $18{ }^{\circ} \mathrm{C}$ and $29^{\circ} \mathrm{C}$. It receives bimodal but unevenly distributed and unreliable rainfall that averages $500 \mathrm{~mm}$ to $1300 \mathrm{~mm}$ annually. The agricultural potential and productivity in terms of livestock type, crop varieties, and actual/potential yield levels is thus highly limited by the low moisture potentials. This increases vulnerability of farmers to production failures. The absolute poverty in the county averages about $61 \%$ [111].

\subsection{Data Collection}

For this study, a cross sectional survey design was used at farm level to collect information from two contrasting agroecological zones through a multistage sampling technique. The AEZ's in terms of counties and sub counties respectively, were selected on the basis of population pressure per square kilometre (high density $>600$, medium density 400-599, and low density $<400$ ), rainfall amount and variability as factors that influence climate change and livelihood vulnerability severity impacts. The sampling frame consisted of a list of farmers from target villages provided by the department of agricultural extension, Likuyani and Mavoko sub counties of Kakamega and Machakos counties respectively. Proportionate stratified random sampling was employed with AEZ used as proxy for water availability, use strategies and salinisation risks in the first stage, hence Machakos and Kakamega counties. During the second stage, population density as a proxy for land subdivision (land size), and therefore the extent of land resource marginalization, was used to select villages where the questionnaires and soil sampling were to take place. The third and final stage employed irrigation typology and water source for irrigation. Households for the administration of the questionnaires 
were then picked through lottery system from a box of cards with numbers generated from a table of random numbers. The semi structured questionnaire was administered between December 2018 and February 2019. The information from household surveys were triangulated through key informant interviews (KI) and focus group discussions (FDGs).

Desk reviews on climate change adaptation policies and environmental governance was also undertaken. Before data collection commenced, the survey questionnaire was tested among 10 respondents to ensure the adequacy of the information obtained and to avoid any ambiguity in the questions. The questionnaire sought information on farmer risk reduction measures concerning soil and water soil testing and associated factors around dissemination of information on salinisation risks. Systematic sampling was employed in the collection of soil and water samples (i.e., on basis of whether ground water (e.g., shallow well, borehole) or surface water (e.g., rivers, roof harvesting) was the main source of irrigation water. Both top soil $(0-20 \mathrm{~cm})$ and subsoils $(20-40 \mathrm{~cm})$ from irrigated and non-irrigated sections of farmers' fields were collect using a soil auger, packed and analysed through AAS (atomic absorption spectrophotometer) and flame photometer at the Kenya Agricultural and Livestock Research (KARLO), Kabete, an ISO/IEC17025 accredited laboratory. This involved composite sampling where top and subsoil subsamples (four) from each farm and sampling point (zigzag transect) were combined to make up a single composite sample. Composite sampling control for spatial and horizontal variations and improves the accuracy in estimation of population parameters which reduces cost and analytical time [112]. It was assumed that each sample contributes an equal amount to the composite sample and the interaction between the sample units would not significantly affect the eventual composite sample.

\subsection{Sample Size Determination}

The study employed Fishers formula [113] in the determination of sample size (Equation (1)).

$$
\mathrm{n}=\mathrm{Z}^{2}\left[\frac{\mathrm{pq}}{\mathrm{d}^{2}}\right]
$$

where $\mathrm{n}=$ desired sample size, $\mathrm{Z}=$ Standard normal deviate at $95 \%$ level of confidence $=1.9$, $\mathrm{P}=$ proportion of target population estimated to have the characteristic under investigation $(10 \%$ or 0.1 ) to maximize sample size (precision), $q=$ proportion of target population without the characteristic $(1-p=90 \%$ or 0.9$), d=$ level of precision corresponding to statistical significance level of 0.05 or $5 \%$. Substituting for the values $\left.n=Z^{2}(p q) / d^{2}\right)=1.96^{2}\left(0.1^{*} 0.9\right) /(0.05)^{2}=138.28$, hence 139 farmers.

Though the desired sample size from Fishers formula (Equation (1)) is 139 households, we adopted fast and frugal heuristics logic to reduce the sample size to 69. In risk analysis, fast and frugal heuristics logic is normally adopted in cases where ignoring some information does not compromise accuracy of the findings [29]. Given that FGDs and KI interviews carried out a priori revealed farmers across the board in the two counties used similar irrigation practices and tended to have similar dispositions about environmental risks, we adopted the same logic to settle at $50 \%$ of the desired sample to maximise precision. The use multistage stratified sampling further justified use of reduced sample size.

\subsection{Data Analysis}

Statistical analysis was performed using generalised linear logistic weight estimation procedure in IBM $^{\mathrm{R}}$ SPSS $^{\mathrm{R}}$ statistics version 26.0 (SPSS Inc., Chicago, IL, USA). A weight estimation procedure computes the coefficients of a linear regression model using weighted least squares (WLS). This ensures that more precise observations (that is, those with less variability) are given greater weight in determining the regression coefficients [114]. WLS thus tests a range of weight transformations that best fit the data. Accordingly, the coefficients selected are those that make the observed results most likely. The weights can be interpreted as a change in the logarithm of the odds ratio $E(\beta)$, associated with a one-unit change in any predictor. The odds equation is given in Equation (1). A negative $E(\beta)$ 
suggests a decreasing likelihood of falling into the target group as you increase predictor variable, while a positive $\mathrm{E}(\beta)$ indicates an increasing likelihood of falling into target group as you increase predictor variable.

$$
\Omega=\mathrm{ez} /(1+\mathrm{ez})
$$

where $\Omega$ is the probability of the event, e is the base of the natural logarithms (2.718), $\mathrm{z}$ is the linear combination and calculated as $z=a+\beta_{1} x_{1}+\beta_{2} x_{2}+\beta_{3} x_{3} \ldots+\beta_{i} x_{i}$. Whereby, $a$ is a constant (intercept) $\beta$ s are coefficients (the log odds) estimated from the data and $x_{i}$ are the values of the predictors.

The $\log$ of the odds ratio $E(\beta)$ or logit expression is given as $\mathrm{z}=\log (\mathrm{p} /(1-\mathrm{p})$ where $\mathrm{P}=$ Probability of falling into target group which is soil/water testing and 1-p = the absence of soil/ water testing on the farm.

Heteroscedasticity which renders estimated $B^{\prime}$ s inefficient and thus invalid for use in making predictions about dependent variable was tested for through Pearson correlations (Table 4). Though a hypothetical dimension of any social phenomenon can be investigated, the responses may be biased especially where farmers are not familiar with the variable being investigated [115]. Since the occurrence of extreme weather and availability of communication media in extension is common in the two study sites, such biases were controlled for in the study. A hypothetical effect of risk dissemination was thus elicited to visualise if it could bias risk perception in terms of practices that impact salinisation risks. Soil (irrigation water) testing was assumed as the appropriate risk mitigation practice against salinisation. A paired t-test of significance was conducted to evaluate the difference in salinity risks associated with irrigation in the topsoil and subsoil $(n=19)$ for the two counties. The quantified changes and significance were assumed to provide time scale scenario of salinity and sodium hazard risks.

The sodium adsorption ration (SAR) was calculated according to [116] given in Equation (3)

$$
\mathrm{SAR}=\frac{\mathrm{Na}}{\sqrt{\frac{1}{2}(\mathrm{Ca}+\mathrm{Mg})}}
$$

where, $\mathrm{Na}=$ Sodium in milliequivalents per litre (me/L), $\mathrm{Ca}=$ Calcium in milliequivalents per litre $(\mathrm{me} / \mathrm{L})$, and $\mathrm{Mg}=$ Magnesium in milliequivalents per litre $(\mathrm{me} / \mathrm{L})$.

\subsection{Student T-Test}

The test of significance relating to each regression coefficient of an explanatory variable $X_{i}$ was made using the $t$-ratio. The $t$-statistic (student $t$ test) tests the hypothesis that corresponding independent variables exerts no statistically significant linear influence on dependent variable for the coefficient. It is a ratio of estimated regression coefficient to its standard error (S.E). In general, the null hypothesis is not rejected if the absolute value of $t$ is less than the value of $t$ corresponding to a particular level of significance and it is rejected if the absolute $t$ exceeds this value. A low t-ratio implies that the coefficient is not significant in determining the dependent variable. If, however, the t-ratio exceeds critical value at chosen significance level, then the coefficient is statistically significant. The $t$-statistic for $\beta_{\mathrm{i}}$ obtained for a sample is given by Equation (4) while Table 1 provides the independent variables used, their description and their levels

$$
\mathrm{t}=\frac{\beta \mathrm{i}}{\hat{\beta}}
$$

where $\mathrm{s}=$ standard deviation of the sample and $\beta_{\mathrm{i}}=$ the estimated value of coefficient. 
Table 1. Description of Independent variables and their levels.

\begin{tabular}{|c|c|c|}
\hline Independent variables & Description & Levels \\
\hline Age $\mathrm{AHH}$ & Age of Household head in years & $1=20-29,2=30-49,3=50-59,4=60-69,5=+70$ \\
\hline Non-farm income level Household Head (NFIHH) & $\begin{array}{l}\text { Level of monthly income from non-farm activities in } \\
\text { Kes/Month by the decision maker }\end{array}$ & $\begin{array}{l}1=<10,000,2=10,000-19,999,3=20,000-19,999, \\
4=20,000-29,999,5=30,000-39,999,6=40,000-49,999, \\
7=>50,000\end{array}$ \\
\hline Farm income household head (FIHH) & $\begin{array}{l}\text { Level of gross crop and livestock revenue on the farm } \\
\text { (Kes/annum) }\end{array}$ & $\begin{array}{l}1=<10,000,2=10,000-19,999,3=20,000-29,999 \\
4=30,000-39,999,4=40,000-49,999,5=>50,000\end{array}$ \\
\hline Highest education level of household head (EHH) & $\begin{array}{l}\text { Highest level of education attained by the } \\
\text { household head }\end{array}$ & $\begin{array}{l}1=\text { none, } 2=\text { Primary, } 3=\text { Postsecondary but not } \\
\text { university, } 4=\text { University and postgraduate }\end{array}$ \\
\hline Are you aware of any risks from water source AWR & Knowledge on potential salinisation risks & $0=\mathrm{No}, 1=\mathrm{Yes}$ \\
\hline Aware of any health risks from water AHR & Main sources of information on health & $0=\mathrm{No}, 1=\mathrm{Yes}$ \\
\hline Aware of any environmental risks AER & $\begin{array}{l}\text { Main source of information on Environmental } \\
\text { management }\end{array}$ & $0=$ No, $1=$ Yes \\
\hline Believe environmental risks can impart negatively BS & $\begin{array}{l}\text { Farmer knowledge on risks associated with salinisation } \\
\text { and their effects }\end{array}$ & $0=\mathrm{No}, 1=\mathrm{Yes}$ \\
\hline Source of information: environmental SIE & Main source of information on irrigation management & $\begin{array}{l}1=\text { electronic media, } 2=\text { print media, } 3=\text { Private } \\
\text { extension, } 4=\text { Public extension, } 5=\text { Radio; } \text { Peers }=6 \text {, } \\
7=\text { Journals }\end{array}$ \\
\hline Source of information: health SIH & Main source of information on health & $\begin{array}{l}1=\text { electronic media, } 2=\text { print media, } 3=\text { Private } \\
\text { extension, } 4=\text { Public extension, } 5=\text { Radio; } \text { Peers }=6 \text {, } \\
7=\text { Journals }\end{array}$ \\
\hline From whom did you learn about irrigation (L)? & $\begin{array}{l}\text { Main sources of information whom the farmer learned } \\
\text { irrigation from }\end{array}$ & $\begin{array}{l}1=\text { electronic media, } 2=\text { print media, } 3=\text { Private } \\
\text { extension, } 4=\text { Public extension, } 5=\text { Radio; } \text { Peers }=6 \text {, } \\
7=\text { Journals }\end{array}$ \\
\hline Types of irrigation (IR) & Types of irrigation technology used on the farm & $1=$ bucket, $2=$ sprinkle, $3=$ Drip, $4=$ flooding \\
\hline $\begin{array}{l}\text { specific messages on potential risks of different water } \\
\text { sources on soil and their control SISST }\end{array}$ & $\begin{array}{l}\text { Whether the farmer received risk messages on } \\
\text { salinisation and their control from extension agents }\end{array}$ & $0=$ No, $1=$ Yes \\
\hline Source of water for irrigation WS & Main source of water used by the farmer & $\begin{array}{l}1=\text { Spring and Rivers, } 2=\text { Ground (borehole or shallow } \\
\text { well, } 3=\text { rain harvesting }\end{array}$ \\
\hline Experience with irrigation (TT) & No. of years the farmer has practiced irrigation & $1=1-4,2=5-9,3=10-15,4=>15$ \\
\hline
\end{tabular}

Source: Authors conceptualisation, 2019. 


\section{Results and Discussion}

The mean parameters of sampled water used in irrigation for the study area is given in Table 2. There was no significance difference in the parameters between the two counties. The mean hydrogen potential $(\mathrm{pH})$ was $7.2 \pm 0.85$ with Machakos being $8.37 \pm 0.789667$ and Kakamega $6.791667 \pm 0.263197$. Though the mean $\mathrm{pH}$ is within the recommended range for most crops, the mean value for Machakos tended towards alkaline with potential to increase salinisation risks. The highest variation in analysed parameters was for chloride levels at $2.4275 \pm 14.89418$, with Machakos at $7.91 \pm 20.98813$ accounting for the highest variation. This is expected as the water sources used varied widely from surface to ground water. The source of water is thus critical with ground water (borehole/shallow wells) in Machakos tending to account for extreme chloride values. The mean SAR levels for Machakos were $1.94 \pm 8.176467$ which increases salinisation risks, while the low levels for Kakamega at $0.14 \pm 0.000418$ posed low salinisation risks.

Table 2. Mean parameters of water used in irrigation, Machakos and Kakamega counties, Kenya.

\begin{tabular}{cccc}
\hline Parameter & Overall & Machakos & Kakamega \\
\hline $\mathrm{Ph}$ & $7.18625 \pm 0.849172$ & $8.37 \pm 0.789667$ & $6.791667 \pm 0.263197$ \\
$\mathrm{EC}(\mathrm{ms} / \mathrm{cm})$ & $0.491875 \pm 0.564456$ & $1.605 \pm 0.6099$ & $0.120833 \pm 0.002627$ \\
$\mathrm{Na}(\mathrm{me} / \mathrm{L})$ & $0.246875 \pm 0.203956$ & $0.84 \pm 0.3936$ & $0.049167 \pm 0.000208$ \\
$\mathrm{~K}(\mathrm{me} / \mathrm{L})$ & $0.02625 \pm 0.000452$ & $0.055 \pm 0.0000433$ & $0.016667 \pm 9.7 \mathrm{E}-05$ \\
$\mathrm{Ca}(\mathrm{me} / \mathrm{L})$ & $0.335 \pm 0.8168$ & $1.125 \pm 2.9647$ & $0.071667 \pm 0.00267$ \\
$\mathrm{Mg}(\mathrm{me} / \mathrm{L})$ & $0.42625 \pm 0.351265$ & $1.1225 \pm 0.798892$ & $0.194167 \pm 0.026081$ \\
Carbonate(me/L) & $0.0275 \pm 0.0065$ & $0.11 \pm 0.0204$ & 0.000 \\
Bicarbonate(me/L) & $0.373125 \pm 0.053236$ & $0.7 \pm 0.060467$ & $0.264167 \pm 0.004299$ \\
Chloride(me/L) & $2.4275 \pm 14.89418$ & $7.91 \pm 20.98813$ & $0.6 \pm 0.012727$ \\
sulphate(me/L) & $0.785 \pm 0.497907$ & $1.1 \pm 1.759267$ & $0.68 \pm 0.151055$ \\
SAR & $0.59 \pm 2.2836$ & $1.94 \pm 8.176467$ & $0.14 \pm 0.000418$ \\
\hline
\end{tabular}

Source: Authors statistical analysis of water samples, 2019.

The statistical analysis for changes in sodium in the topsoil (ESP), an indicator of soil salinity hazards is given in Table 3. There is significant difference in salinity hazards in the top soil with irrigation especially for soils in Kakamega county study site. The mean ESP in top and subsoil in Kakamega was $5.65 \pm 3.73$ and $5.91 \pm 0.70 \mathrm{Me} \%$ respectively. The mean change in ESP was significant in both sites. The ESP for Kakamega changed by $0.66 \pm 0.73$ and $-0.08 \pm 0.40 \mathrm{Me} \%$ in top and subsoil respectively. The mean change in ESP for Machakos's study site was 0.033 \pm 0.47 and $2.22 \pm 28.21 \mathrm{Me} \%$ in top and subsoil respectively. The overall change for the two sites with irrigation in the topsoil and subsoil was $0.45 \pm 0.70$ and $0.69 \pm 9.8$ Me respectively. The overall negative changes in ESP values for top soil imply displacement or desorption of calcium $\left(\mathrm{ca}^{++}\right)$, Potassium $\left(\mathrm{k}^{+}\right)$and Magnesium $(\mathrm{mg}++)$, the bases that jointly determine cation exchange capacity (CEC), an indicator of soil fertility levels, as more of $\mathrm{Na}+$ is being adsorbed on the soil colloids. The increase in $\mathrm{Na}^{+}$is indicative of soil degradation in terms of dispersion, poor permeability and loss of soil structure risks. The net negative change (decrease) in topsoil is indicative of soil degradation risks while the positive changes (increase) in subsoil soils is attributed to leaching of salts and potentially the degradation of underground water resources over a long planning horizon.

The increase in subsoil $\mathrm{Na}^{+}$levels for both sites could be attributed to leaching of salts under irrigation with high variation in Machakos $(2.22 \pm 28.21)$ reflecting the high SAR levels, as well as the high variability of the parameter in water sources (Table 2) utilised for irrigation. The overall mean ESP for both sites was 4.2 with a change of 0.45 in top soil and $4.56 \mathrm{me} \%$ in subsoil, a change of $0.69 \mathrm{me} \%$. Overall, irrigation increased ESP in both sites (Table 4), an indicator of soil degradation risks. The two sample F test for variance in Sodium concentration is negative, an indication of increased and high sodicity risks in Kakamega. Though primary salinisation effects were not determined, the increase in sodium concertation with irrigation is indicative of soil quality degradation risks in autonomous adaptation. 
Table 3. Paired Two Sample test for Means of ESP (me\%) and changes with irrigation $(\mathrm{N}=19)$.

\begin{tabular}{|c|c|c|c|c|c|c|}
\hline & & Treatment & Mean & $\mathbf{T}$ & Critical t-Value & Sig \\
\hline \multirow{2}{*}{ Kakamega $(\mathrm{n}=13)$} & Topsoil & $\begin{array}{c}\text { Non-irrigated } \\
\text { Change with Irrigation }\end{array}$ & $\begin{array}{c}5.6 \pm 3.73 \\
0.66 \pm 0.73\end{array}$ & -7.57 & 1.8 & ** \\
\hline & Subsoil & $\begin{array}{c}\text { Non-irrigated } \\
\text { Change with Irrigation }\end{array}$ & $\begin{array}{c}5.91 \pm 0.70 \\
-0.08 \pm 0.40\end{array}$ & -24.65 & 1.8 & $* *$ \\
\hline \multirow[b]{2}{*}{ Machakos $(n=6)$} & Topsoil & Non-irrigated & $\begin{array}{c}1.4 \pm 0.428 \\
0.033+0.47\end{array}$ & -3.69 & 2.01 & ** \\
\hline & Subsoil & $\begin{array}{l}\text { Non-irrigated } \\
\text { Change with Irrigation }\end{array}$ & $\begin{array}{c}1.85 \pm 0.84 \\
2.22 \pm 28.21\end{array}$ & 0.201 & 2.01 & $* *$ \\
\hline \multirow{2}{*}{ Overall $(n=19)$} & Topsoil & $\begin{array}{c}\text { Non-Irrigated } \\
\text { Change with Irrigation }\end{array}$ & $\begin{array}{c}4.2 \pm 6.69 \\
0.45 \pm 0.70\end{array}$ & -6.21 & 1.74 & $* *$ \\
\hline & Subsoil & $\begin{array}{c}\text { Non-Irrigated } \\
\text { Change with Irrigation }\end{array}$ & $\begin{array}{c}4.56 \pm 4.56 \\
0.69 \pm 9.8\end{array}$ & -4.12 & 1.74 & $* *$ \\
\hline
\end{tabular}

Source: Authors Statistical analysis of Soil samples, ${ }^{* *}$ Significant at 0.05 and 0.001 .

Table 4. Two-Sample F-Test for Variance in topsoil sodium concentration (SAR) with irrigation.

\begin{tabular}{ccc}
\hline & Kakamega & Machakos \\
\hline Mean & -0.00769 & 0.133333 \\
Variance & 0.001 & 0.063 \\
Observations & 13 & 6 \\
Df & 12 & 5 \\
F & 0.012275 & \\
$\mathrm{P}(\mathrm{F}<=$ f) one-tail & $7.76 \mathrm{E}-09^{* *}$ & \\
F Critical one-tail & 0.32197 &
\end{tabular}

Source: Authors analysis of soil and water laboratory statistical analysis, $2019 ;{ }^{* *}$ significant at $0.05 \%$.

Table 5 presents Pearsons correlation on a number of factors influencing soil testing in the two study counties. There is a positive correlation between education and income, awareness on risks on water, as well as the positive risk reduction inform of soil/water testing. However, age has a negative correlation on soil (water) testing and salinisation risk reduction. Nonetheless, the more aged believe environmental risks could negatively impart them. Age is also negatively correlated to source of information. Possibly, old farmers tend to rely more on informal sources of information, such as their peers and not the ubiquitous electronic and mass media sources. Age is also negatively correlated with income suggesting that it may constraint adoption of soil testing advisories. In absence of risk communication messages, all the predictors (Table 5) are statistically insignificant in salinisation risk reduction.

Human capital theory [117], identifies innovative ability as closely related to education level, farming experience (proxy for age), and information accumulation. The positive effect observed for education on the adoption of soil testing though not significant is consistent with human capital theory in Agriculture. However, the negative correlation between the number of years spent using of technology (an indirect proxy for age) and perception of harm from environmental risks is consistent with risk normalisation theory [87]. The choice of channels of communication and their effectiveness is thus a critical policy consideration in transformative adaptation and sustainability discourses. 
Table 5. Pearson correlations on factors influencing soil testing in Kakamega and Machakos counties, Kenya.

\begin{tabular}{|c|c|c|c|c|c|c|c|c|c|c|c|c|c|c|c|}
\hline & (Intercept) & Age & NFIHH & FHH & EHH & AWR & WS & AHR & AER & SIH & BS & SIE & $\mathbf{L}$ & SISST & IR \\
\hline (Intercept) & 1.000 & & & & & & & & & & & & & & \\
\hline Age & -0.416 & 1.000 & & & & & & & & & & & & & \\
\hline Non-farm income level household head (NFIHH) & -0.320 & -0.264 & 1.000 & & & & & & & & & & & & \\
\hline Farm income household head (FIHH) & -0.536 & 0.194 & 0.377 & 1.000 & & & & & & & & & & & \\
\hline Highest education level - house head (EHH) & 0.131 & 0.476 & -0.926 & -0.31 & 1.000 & & & & & & & & & & \\
\hline Are you aware of any risks from water source (AWR) & 0.075 & -0.781 & 0.393 & -0.195 & -0.566 & 1.000 & & & & & & & & & \\
\hline Source of water (WS) & -0.568 & 0.399 & -0.210 & 0.221 & 0.381 & -0.234 & 1.000 & & & & & & & & \\
\hline aware of any health risks from water (AHR) & -0.348 & -0.567 & 0.537 & 0.100 & -0.622 & 0.611 & -0.141 & 1.000 & & & & & & & \\
\hline aware of any environmental risks (AER) & -0.299 & -0.557 & 0.065 & 0.054 & -0.202 & 0.640 & 0.159 & 0.632 & 1.000 & & & & & & \\
\hline Source of information- health & -0.522 & -0.269 & 0.667 & 0.124 & -0.627 & 0.521 & 0.162 & 0.686 & 0.479 & 1.000 & & & & & \\
\hline believe environmental risk can impart negatively (BS) & -0.048 & -0.064 & -0.213 & -0.219 & 0.130 & 0.164 & 0.336 & 0.044 & 0.281 & 0.076 & 1.000 & & & & \\
\hline Source of information: environmental (SIE) & -0.473 & -0.027 & 0.668 & 0.445 & -0.647 & 0.222 & 0.013 & 0.427 & 0.153 & 0.575 & 0.302 & 1.000 & & & \\
\hline From whom did you get to learn about irrigation (L)? & -0.080 & 0.399 & -0.469 & 0.044 & 0.534 & -0.379 & 0.062 & -0.424 & -0.185 & -0.484 & -0.406 & -0.550 & 1.000 & & \\
\hline $\begin{array}{l}\text { specific messages on potential risks of different water } \\
\text { sources on soil and their control (SISST) }\end{array}$ & -0.004 & 0.643 & 0.095 & 0.062 & 0.127 & -0.587 & 0.042 & -0.539 & -0.860 & -0.262 & -0.418 & -0.055 & 0.244 & 1.000 & \\
\hline Types of irrigation (IR) & -0.115 & -0.605 & 0.057 & -0.089 & -0.242 & 0.698 & -0.102 & 0.542 & 0.878 & 0.343 & 0.185 & -0.004 & -0.071 & -0.877 & 1.000 \\
\hline
\end{tabular}


The communication perspective is critical in risk dissemination and sustainability discourses in climate change adaptation [117-119]. Information improves farmer's human capital, reduces risk and uncertainty in technology adoption process [120]. In this study, the negative correlation between information source and education in risk reduction behaviour is possibly related to biased access of information as the level of education increases. Further, the findings suggest a gap in the current research-extension linkages where access to information sources, such as scientific journals that are more likely to disseminate information on environmental externalities as opposed to the conventional sources, such as the radio are by default biased towards farmers with high levels of education. Since the effect of risk dissemination is negatively correlated with source of information, it suggests that the current sources of information are ineffective and/or do not disseminate information concerning the existing risks. Implicit in this is the need for transformative lenses to enhance the role of media, both electronic and print in risk information dissemination especially as it relates to secondary risks in climate change adaptation.

Table 6 provides the odds ratio $\mathrm{E}(\beta)$, generalised logistic parameter estimates on soil testing as a risk reduction measure and control of irrigation related risks. An odds ratio less than one connotes that the variable decreases the likelihood of adoption, whereas an odds ratio greater than one means that the variable increases the likelihood of adoption. The likelihood of the odds ratio on age, farm income (farm and non-farm), number of years in use of technology, and source of information, education, awareness on health risks, type of, irrigation though not statistically significant had negative odds ratios. In the absence of risk message dissemination, there is a decreased likelihood of soil testing with increase in value of the mentioned variables. From existing literature, risk aversion increases with age hence the negative sign for age in our study is expected. However, education, income, and experience tend to be positively correlated with adoption. This observation suggests that existing technology diffusion and adoption models and human capital theory in agriculture cannot be used effectively to address environmental externalities in adaptation planning.

Table 6. Generalised linear logistic parameter estimates on soil testing without dissemination of risk messages.

\begin{tabular}{|c|c|c|c|c|c|c|c|c|c|}
\hline \multirow{2}{*}{ Parameter } & \multirow{2}{*}{ B } & \multirow{2}{*}{ Std. Error } & \multicolumn{4}{|c|}{ Unstandardized $95 \%$ Wald Confidence Interval } & \multicolumn{3}{|c|}{ Standardized $95 \%$ Wald Confidence } \\
\hline & & & Lower & Upper & Wald $\chi^{2}$ & Sig. & $\operatorname{Exp}(\beta)$ & Lower & Upper \\
\hline (Intercept) & -22.572 & 1.6028 & -25.714 & -19.431 & 198.329 & 0.000 & $1.574 \mathrm{E}-10$ & $6.803 \mathrm{E}-12$ & $3.642 \mathrm{E}-9$ \\
\hline NFIHH & -0.075 & 0.2073 & -0.481 & 0.332 & 0.130 & 0.719 & 0.928 & 0.618 & 1.393 \\
\hline FIHH & -0.110 & 0.1665 & -0.436 & 0.217 & 0.433 & 0.510 & 0.896 & 0.647 & 1.242 \\
\hline EDHH & 0.186 & 0.3147 & -0.431 & 0.803 & 0.350 & 0.554 & 1.205 & 0.650 & 2.232 \\
\hline AHR & -0.224 & 1.0522 & -2.286 & 1.838 & 0.045 & 0.832 & 0.799 & 0.102 & 6.287 \\
\hline AER & -0.414 & 0.7711 & -1.926 & 1.097 & 0.289 & 0.591 & 0.661 & 0.146 & 2.996 \\
\hline $\mathrm{SIH}$ & -0.033 & 0.0847 & -0.199 & 0.133 & 0.154 & 0.695 & 0.967 & 0.819 & 1.142 \\
\hline BS & -0.089 & 0.4321 & -0.936 & 0.758 & 0.042 & 0.837 & 0.915 & 0.392 & 2.134 \\
\hline SIE & -0.003 & 0.0738 & -0.148 & 0.141 & 0.002 & 0.966 & 0.997 & 0.863 & 1.152 \\
\hline TT & 0.004 & 0.0694 & -0.132 & 0.140 & 0.003 & 0.957 & 1.004 & 0.876 & 1.150 \\
\hline
\end{tabular}

Source: Authors statistical analysis of field data, 2019. Likelihood Ratio Chi-Square $\left(\chi^{2}\right)=10.858 ; p=0.286$, df $=9$.

The positive effect of risk message dissemination on risk behaviour has been observed by several authors $[21,63,86]$. The generalised linear logistic parameter estimates (Table 8) explains the effect of risk message dissemination on soil testing. In this study, dissemination of risk messages could have significant impact on likelihood of positive change on risk belief and mitigation action. This is consistent with some findings on rapid onset disasters, such as earthquakes where higher education levels, higher income and greater experience with previous emergencies is significantly associated with higher preparedness [121]. In our study, risk message dissemination has positive significant 
effect on farmers disposition about salinisation risks with majority of the farmers who would change their behaviour (adopt soil testing as a risk reduction measure) falling in the 30-49 year age category (Table 7).

Table 7. Proportion of change in action for soil testing if risk message were disseminated.

\begin{tabular}{ccccc}
\hline Age Category & No & Yes & Total & \% Change \\
\hline $20-29$ & 5 & 2 & 7 & 3.13 \\
$30-49$ & 15 & 18 & 33 & 28.13 \\
$50-59$ & 8 & 6 & 14 & 9.38 \\
$60-69$ & 3 & 6 & 9 & 9.38 \\
70 and above & 0 & 1 & 1 & 1.6 \\
Total & 31 & 33 & 65 & 51.62 \\
\hline \multicolumn{4}{r}{ Source: Authors analysis of field data. }
\end{tabular}

Likewise, according to Table 8, dissemination of risk message has significant positive impact on likelihood in change of choice of water sources (WS) for irrigation and type of irrigation (i.e., bucket, sprinkle, surface and drip), all which impact salinity hazards. Additionally, risk message dissemination significantly increases the likelihood of soil testing for every additional level (higher level) of farmer education and the positively correlated non-farm income. However, dissemination of risk messages decreases the likelihood in soil testing when awareness on water and environmental risks are taken into account. This could be due to other factors, notably the extra costs incurred in soil testing as source of risk that decreases profit levels in the short term. The observation is consistent with [69], that gaps between information dissemination and level of implementation could be as a result of subjective limits or considerations for factors that impact profit and/or cost in adoption of risk reduction behaviour. Factors that lower profits or increase expenses are sources of risk (i.e., technical, price, legal, social and human), that adversely impact the economic performance hence farmers' decision making [121-124]. The finding underscores Howden et al. [125], and Koundouri et al. [120], that policy makers in adaptation planning need to increase their attention on the role of risk attitude in technology adoption.

Table 8. Generalised Linear logistic Parameter Estimates on soil testing with dissemination of risk messages.

\begin{tabular}{|c|c|c|c|c|c|c|c|c|c|}
\hline \multirow{2}{*}{ Parameter } & \multirow{2}{*}{ B } & \multirow{2}{*}{ Std. Error } & \multicolumn{4}{|c|}{ Unstandardized $95 \%$ Wald Confidence Interval } & \multicolumn{3}{|c|}{ Standardized $95 \%$ Wald Confidence Interval } \\
\hline & & & Lower & Upper & Wald $\chi^{2}$ & Sig. & $\operatorname{Exp}(\beta)$ & Lower & Upper \\
\hline Intercept & -84.523 & 4.1365 & -92.631 & -76.416 & 417.521 & 0.000 & $1.959 \mathrm{E}-37$ & $5.902 \mathrm{E}-41$ & $6.502 \mathrm{E}-34$ \\
\hline Age & 2.782 & 1.0189 & 0.785 & 4.779 & 7.454 & 0.006 & 16.148 & 2.192 & 118.961 \\
\hline $\mathrm{FIHH}$ & -1.196 & 0.3775 & -1.936 & -0.457 & 10.045 & 0.002 & 0.302 & 0.144 & 0.633 \\
\hline $\mathrm{EHH}$ & 0.642 & 0.9184 & -1.158 & 2.442 & 0.488 & 0.485 & 1.899 & 0.314 & 11.491 \\
\hline AWR & -9.560 & 2.4241 & -14.311 & -4.809 & 15.553 & 0.000 & 7.052E-5 & $6.094 \mathrm{E}-7$ & 0.008 \\
\hline AHR & 7.723 & 2.4725 & 2.877 & 12.569 & 9.755 & 0.002 & 2258.738 & 17.752 & $287,391.934$ \\
\hline AER & -9.136 & 1.8365 & -12.735 & -5.537 & 24.748 & 0.000 & 0.000 & $2.945 \mathrm{E}-6$ & 0.004 \\
\hline $\mathrm{SIH}$ & 0.753 & 0.2005 & 0.360 & 1.146 & 14.085 & 0.000 & 2.123 & 1.433 & 3.145 \\
\hline BS & 7.058 & 0.7838 & 5.522 & 8.594 & 81.096 & 0.000 & 1162.039 & 250.086 & 5399.470 \\
\hline SIE & 0.228 & 0.1929 & -0.150 & 0.606 & 1.400 & 0.237 & 1.256 & 0.861 & 1.834 \\
\hline $\mathrm{L}$ & -0.519 & 0.1158 & -0.746 & -0.292 & 20.089 & 0.000 & 0.595 & 0.474 & 0.747 \\
\hline
\end{tabular}

Source: Authors statistical analysis of field data, 2019. Likelihood Ratio Chi-Square $\left(\chi^{2}\right)=1.742 \mathrm{E}^{10}, \mathrm{Df}=7 ; \mathrm{P}=0.000$ ***; significant at $0.001 \%$.

The significant decrease in likelihood of soil testing with risk message dissemination when the number of years the farmer has used a given irrigation technology is taken into account could be attributed to resource fixity in agricultural production (i.e., difficulty in changing irrigation infrastructure to alternative uses) and attendant risks and/or low risk belief about salinisation risks among farmers. The observation is also consistent with existing literature on determinants of cognitive bias, such as, 
personal experience, knowledge (level of education), extension education, which individually or severally impact cognitive ability and the accuracy of climate information processing [82]. The inherent social and environmental costs in maladaptive projects and their premature decommissioning at a future date may impose high opportunity costs to society at large when adaptation policy and practice ignores the integration of environmental spillover mitigation into planning. The observation highlights the need for system approach and innovative use of communication as a tool for proactive risk reduction and effective adaptation planning.

Managing environmental risks in climate change action inadvertently touches on governance in terms of roles, availing of relevant information, policy and legislative frameworks, risk control guidelines, as well as, coordination mechanism that are responsive to the present and future needs of society [81]. The role of governance on soil testing as a risk management strategy was undertaken through KI, FGDs and desk reviews. The findings revealed key governance gaps, particularly fragmented approaches and coordination among government agencies, low awareness about salinisation risks among farmers and extension agencies, all of which constitute cognitive failure about environmental spillovers in climate change adaptation. Though the object of the climate action planning is to integrate climate risk and vulnerability assessment into all forms of assessment, and for that purpose, to liaise with relevant lead agencies for their technical advice, it tends to focus only on methane emissions and fail to acknowledge the diverse array of environmental spillovers, such as the salinisation risks in irrigation.

In the study area, a lack of coordinated approaches among various agencies was noted. Further, interviews with farmers and analysis of KI interviews revealed that neither the climate change Act nor EMCA identifies salinisation externalities. The cognitive failure was more apparent in extension agencies from both counties. According to KI interviews, the extension agents were more focused on supply and demand needs with irrigation, a routine adjustment and solution to increasingly risky rain fed systems, being recommended to the exclusion of underlying environmental concerns. This seems to be a popular discourse among policy makers, farmers and practionneers in the country.

Some of the projects are funded by the central and county governments against tight timelines, for example emergence drought recovery interventions which tend to be accorded high attention by the political class. We focus on technological dimensions, that is, the agronomic aspects, such as fertilizer types, choice of variety and which are farmer felt needs, but not the environmental spillovers. In any case we have not been notified of any environmental breaches by NEMA agricultural extension officers in the two counties.

The above finding suggest low institutional awareness and fragmented approach, a finding that is consistent with Seidler et al. [6] and Ayers et al. [12], respectively, on determinants of adaptation failure. In addition, an extension officer, Machakos county, had this to say:

"The farmers have not reported any problems with water sources for irrigation except for one borehole in the neighbourhood ... We suspect salinity issues but so far we haven't verified whether the borehole was unsuitable for irrigation or the abandonment was due to other causes" - An agricultural extension officer, Machakos County.

Analysis of water sample from the above-mentioned borehole revealed extremely high salinity and its unsuitability for irrigation. In absence of robust mitigation measures suggested by FAO [33], such as annual soil testing, mixing of rain and borehole water sources, adequate drainage as well as deep tillage, drainage canals, application of manure in large amounts to improve infiltration rate and/or planting crops with good salt tolerance being instituted, there is an increased risk in salinisation and land degradation. Of great concern among surveyed farmers (Table 9) was the widespread ignorance about salinity risks from water sources and their mitigation. The observation is reflective of high level of cognitive failure on soil testing as a risk reduction measure among small scale farmers and government agencies in the two counties. Of the surveyed households, a majority (about 98\%) had not undertaken soil testing, with less than $10 \%$ of the farmers being aware of salinisation risks. There is a 
gap in awareness and mitigation. Risk aversion seems to be the explanation for the gap. The farmers had this to say;

Table 9. Farmers undertaking soil testing as a risk reduction measure in Kakamega and Machakos counties, Kenya.

\begin{tabular}{ccccc}
\hline Age & No & Yes & Total & \% Testing Soil \\
\hline $20-29$ & 7 & $0(0)$ & 7 & $0(0)$ \\
$30-49$ & 33 & $1(3)$ & 34 & $1.54(4.6)$ \\
$50-59$ & 14 & $0(2)$ & 14 & $0(3.1)$ \\
$60-69$ & 9 & $0(1)$ & 9 & $0(1.54)$ \\
70 and above & 1 & $0(0)$ & 1 & $0(0)$ \\
Total & 64 & $1(6)$ & 65 & $1.54(9.24)$ \\
\hline
\end{tabular}

Source: Authors statistical analysis of survey data. Figures in brackets indicate those who are aware about risks from water (salinisation risks).

"The frequent droughts have negatively affected our livelihoods yet our ability to respond to it is heavily constrained as we have low incomes. We don't think there are environmental risks other than the problematic pests and diseases that trouble us. If there were environmental risks, we would have heard from some of the extension programmes on radio and the extension officers who rarely visit our farms. In any case we think it could be costly testing the soil and water unless the relevant government agencies provide such services for free"-Farmer FGDs in Kakamega and Machakos counties.

The cognitive failure across individuals and institutions in adaptation planning in the study area reflect the governance gaps about environmental externalities. The pervasiveness of cognition failure, as manifested through low awareness among farmers and government agencies alike, as well as poor coordination among formal agencies especially agricultural extension services, is indicative of ineffective adaptation planning frameworks in the counties and the country at large.

$\mathrm{Mu}$ et al. [69], explains the variance between awareness and implementation in terms of profit motives. This may account for the observed negative odds likelihood between risk message dissemination on choice of water source for irrigation. The negative likelihood has profound policy implication and the management of underlying risks, such as the environmental spillovers. Though the risk reduction focused climate change Act has potential to address some of the demand-supply needs and production risks, it fails to recognise the negative environmental spillovers. The cognitive failure is reflected in low institutional attention accorded to slow onset disasters in the NAPAs among lead and regulatory agencies. For example, salinisation risks were not mentioned nor captured as concerns that need monitoring. The cognitive failure is aptly reflected in a lack of mention of salinisation risks and their mitigation in the Environmental Management Plan (EMP) section of environmental impact assessments (EIAs) reports on irrigation undertaken nationally and the study sites.

\section{Conclusions}

Poor system integration, as well as low attention to spillover systems across scale, especially the low attention to time related integration needs in adaptation planning has potential to exacerbate less recognised slow onset disaster risks, such as salinisation. In absence of a transformative and system approach, failure to identify and internalise the individual and cumulative impacts of the seemingly minor footprints could over time substantially increase land degradation risks and impose costs on the society at large. In this study we explored farmer perception on slow onset disasters and how it constraints transformative adaptation. Specifically, the role of cognition or perception in mobilising peoples' commitment to action over negative environmental externalities, risk belief and mitigation action has been highlighted. The findings suggest that multifaceted biases and failures about the existence and importance of externalities across scale, a critical gap in adaptation planning discourses, is exacerbated through low awareness, fragmented approaches and technological biased lenses among actors in adaptation planning. 
Under diverse social-economic contexts education level, farming experience, and information accumulation as human capital components significantly account for adoption of technologies in conventional technology diffusion trajectories. However, from this study, the human capital components do not significantly influence risk reduction behaviour concerning environmental spillovers in absence of risk message information. The failure by diverse actors across scale to recognise the externalities, as well as the low institutional awareness constitute cognitive failure with potential to undermine ecosystems, farmer adaptive capacity and livelihoods in the long run. Transformative adaptation policy framing and information support frameworks have great potential to guide informed decision making and a paradigm shift towards effective adaptation action, learning and mitigation of environmental externalities. This is particularly relevant for slow onset disasters, such as salinisation related land degradation risks, where lack and /or poor knowledge of the consequences of the effect resonates with the narrative of wicked environmental problems and adaptation failure. Electronic and print media could compliment conventional extension strategies in risk information dissemination, especially as relates to the mitigation of secondary risks in climate change adaptation.

Author Contributions: V.T.E. conceived the basic idea of the study. V.T.E. and J.O.O. designed the structure of the study. V.T.E. wrote while J.O.O. revised the manuscript. Both authors approved the final version of manuscript. All authors have read and agreed to the published version of the manuscript.

Funding: This research received no external funding.

Acknowledgments: We acknowledge farmers in Likuyani and Mavoko sub counties and respective extension staff, Ministry of Agriculture whose support enabled us to collect the relevant data, as well as the comments of three anonymous reviewers who greatly contributed to the improvement of the manuscript.

Conflicts of Interest: The authors declare no conflict of interest. This research did not receive any specific grant from funding agencies in the public, commercial, or not-for-profit sectors.

\section{References}

1. Pelling, M.; O’Brien, K.; Matyas, D. Adaptation and transformation. Clim. Chang. 2015, 133, $113-127$. [CrossRef]

2. Pahl-Wostl, C. A conceptual framework for analysing adaptive capacity and multi-level learning processes in resource governance regimes. Glob. Environ. Chang. 2009, 19, 354-365. [CrossRef]

3. Rijke, J.; Brown, R.; Zevenbergen, C.; Ashley, R.; Farrelly, M.; Morison, P.; Herk, S. Van Fit-for-purpose governance: A framework to make adaptive governance operational. Environ. Sci. Policy 2012, 22, $73-84$. [CrossRef]

4. United Nations. Transforming the World: The 2030 Agenda for Sustainable Development; United Nations: New York, NY, USA, 2015; A/RES/70/1.

5. United Nations International Strategy for Disaster Reduction. Sendai Framework for Disaster Risk Reduction 2015-2030; UN: Sendai, Japan, 2015.

6. Seidler, R.; Dietrich, K.; Schweizer, S.; Bawa, K.S.; Chopde, S.; Zaman, F.; Sharma, A.; Bhattacharya, S.; Devkota, L.P.; Khaling, S.; et al. Progress on integrating climate change adaptation and disaster risk reduction for sustainable development pathways in South Asia: Evidence from six research projects. Int. J. Disaster Risk Reduct. 2018, 31, 92-101. [CrossRef]

7. Liu, J.; Mooney, H.; Hull, V.; Davis, S.; Gaskell, J.; Hertel, T.; Lubchenco, J.; Seto, K.; Gleick, P.; Kremen, C.; et al. Systems integration. Sustainability 2015, 347, 963-971.

8. $\quad$ Reed, M.S.; Podesta, G.; Fazey, I.; Geeson, N.; Hessel, R.; Hubacek, K.; Letson, D.; Nainggolan, D.; Prell, C.; Rickenbach, M.G.; et al. Combining analytical frameworks to assess livelihood vulnerability to climate change and analyse adaptation options. Ecol. Econ. 2013, 94, 66-77. [CrossRef]

9. Park, S.E.; Marshall, N.A.; Jakku, E.; Dowd, A.M.; Howden, S.M.; Mendham, E.; Fleming, A. Informing adaptation responses to climate change through theories of transformation. Glob. Environ. Chang. 2012, 22, 115-126. [CrossRef] 
10. Nagoda, S. New discourses but same old development approaches? Climate change adaptation policies, chronic food insecurity and development interventions in northwestern Nepal. Glob. Environ. Chang. 2015, 35, 570-579. [CrossRef]

11. Berkes, F.; Ross, H. Community Resilience: Toward an Integrated Approach Community Resilience: Toward an Integrated Approach. Soc. Nat. Resour. 2013, 26, 5-20. [CrossRef]

12. Ayers, J.; Huq, S.; Wright, H.; Faisal, A.M.; Tanveer, S. Mainstreaming climate change adaptation into development in Bangladesh. Clim. Dev. 2014, 6, 293-305. [CrossRef]

13. Huq, N.; Renaud, F.; Sebesvari, Z. Ecosytem Based Adaptation (EbA) to Climate Change-Integrating Actions to Sustainable Adaptation; Institute for Environmental and Human Security, United Nations University: Bonn, Germany, 2013.

14. Wise, R.M.; Fazey, I.; Smith, M.S.; Park, S.E.; Eakin, H.C.; Van Garderen, E.R.M.A.; Campbell, B. Reconceptualising adaptation to climate change as part of pathways of change and response. Glob. Environ. Chang. 2014, 28, 325-336. [CrossRef]

15. Stafford Smith, M.; Harrocks, L.; Harvey, A.; Hamilton, C. Rethinking adaptation for a $4{ }^{\circ} \mathrm{C}$ world. Philos. Trans. R. Soc. A 2011, 369, 196-216. [CrossRef] [PubMed]

16. Nelson, D.R.; Adger, W.N.; Brown, K. Adaptation to Environmental Change: Contributions of a Resilience Framework. Annu. Rev. Environ. Resour. 2007, 32, 395-419. [CrossRef]

17. Dupuis, J.; Knoepfel, P. The Adaptation Policy Paradox: The Implementation Deficit of Policies. Ecol. Soc. 2013, 18, 31-47. [CrossRef]

18. Stirling, A. Opening up or closing down? Analysis, participation and power in the social appraisal of technology. In Science and Citizen: Globalization and the Challenge of Engagement; Leach, M., Scoones, L., Wynne, B., Eds.; ZeD Books: London, UK, 2005; pp. 218-231. ISBN 1842775502.

19. Brown, K. Sustainable adaptation: An oxymoron? Clim. Dev. 2011, 5529, 20-31. [CrossRef]

20. Schipper, L.; Pelling, M. Disaster risk, climate change and international development: Scope for, and challenges to, integration. Disasters 2006, 30, 19-38. [CrossRef]

21. Adger, W.N.; Dessai, S.; Goulden, M.; Hulme, M.; Lorenzoni, I.; Nelson, D.R.; Otto, L.; Johanna, N.; Anita, W. Are there social limits to adaptation to climate change? Clim. Chang. 2009, 93, 335-354. [CrossRef]

22. Gostin, L.; Lucey, D.; Phelan, A. The Ebola Epidemic A Global Health Emergency. JAMA 2014, 312, $1095-1096$. [CrossRef]

23. Pelling, M.; Manuel-Navarrete, D. From Resilience to Transformation: The Adaptive Cycle in Two Mexican Urban Centers. Ecol. Soc. 2011, 16, 11-22. [CrossRef]

24. Ostrom, E. A diagnostic approach for going beyond panaceas. Proc. Natl. Acad. Sci. USA 2007, 104, 15181-15187. [CrossRef]

25. Paavola, J.; Gouldson, A.; Kluvánková-Oravská, T. Interplay of Actors, Scales, Frameworks and Regimes in the Governance of Biodiversity. Environ. Policy Gov. 2009, 158, 148-158. [CrossRef]

26. Karpouzoglou, T.; Dewulf, A.; Clark, J. Advancing adaptive governance of social-ecological systems through theoretical multiplicity. Environ. Sci. Policy 2016, 57, 1-9. [CrossRef]

27. Liu, J.; Yang, W. Integrated assessments of payments for ecosystem services programs. Proc. Natl. Acad. Sci. USA 2013, 110, 16297-16298. [CrossRef] [PubMed]

28. Suckall, N.; Tompkins, E.; Stringer, L. Identifying trade-offs between adaptation, mitigation and development in community responses to climate and socio-economic stresses: Evidence from Zanzibar, Tanzania. Appl. Geogr. 2014, 46, 111-121. [CrossRef]

29. Hafenbrädl, S.; Haven, N.; States, U.; Waeger, D.; Marewski, J.N. Applied Decision Making With Fast-and-Frugal Heuristics. J. Appl. Res. Mem. Cogn. 2016, 5, 215-231. [CrossRef]

30. Reed, M.S.; Fraser, E.D.G.; Dougill, A.J. An adaptive learning process for developing and applying sustainability indicators with local communities. Ecol. Econ. 2006, 59, 406-418. [CrossRef]

31. Reid, P.; Coleen, V. Living and responding to multiple stressors in South Africa-Glimpses from KwaZulu-Natal. Glob. Environ. Chang. 2006, 16, 195-206. [CrossRef]

32. Metternicht, G.I.; Zinck, J.A. Remote sensing of soil salinity: Potentials and constraints. Remote Sens. Environ. 2003, 85, 1-20. [CrossRef]

33. FAO. Water Quality for Agriculture; Food and Agricultue Organisation of the United Nations: Rome, Italy, 1985. 
34. Jung, T.; Srinivasan, A.; Tamura, K.; Sudo, T.; Watanabe, R.; Shimada, K.; Kimura, H. Asian Perspectives on Climate Regime Beyond 2012: Concerns, Interests and Priorities; Istitute for Global Environmental Strategies: Hayama, Japan, 2005.

35. Haddad, B.M. Ranking the adaptive capacity of nations to climate change when socio-political goals are explicit. Glob. Environ. Chang. 2005, 15, 165-176. [CrossRef]

36. Füssel, H.M. Adaptation planning for climate change: Concepts, assessment approaches, and key lessons. Sustain. Sci. 2007, 2, 265-275. [CrossRef]

37. Adger, W.N.; Arnell, N.W.; Tompkins, E.L. Successful adaptation to climate change across scales. Glob. Environ. Chang. 2005, 15, 77-86. [CrossRef]

38. Barnett, J.; O'Neill, S. Maladaptation. Glob. Environ. Chang. 2010, 20, 211-213. [CrossRef]

39. Mustafa, D. The Production of an Urban Hazardscape in Pakistan: Modernity, Vulnerability, and the Range of Choice. Ann. Assoc. Am. Geogr. 2005, 95, 566-586. [CrossRef]

40. Bizikova, L.; Robinson, J.; Cohen, S. Linking climate change and sustainable development at the local level. Clim. Policy 2007, 7, 271-277. [CrossRef]

41. Butler, J.R.A.; Suadnya, W.; Puspadi, K.; Sutaryono, Y.; Wise, R.M.; Skewes, T.D.; Kirono, D.; Bohensky, E.L.; Handayani, T.; Habibi, P.; et al. Framing the application of adaptation pathways for rural livelihoods and global change in eastern Indonesian islands. Glob. Environ. Chang. 2014, 28, 368-382. [CrossRef]

42. Adger, N.; Aggarwal, P.; Agrawala, S.; Alcamo, J.; Allali, A.; Cruz, R.; Alcaraz, E.D.A.; Easterling, W.; Field, C.; Fischlin, A.; et al. Climate Change 2007: Impacts, Adaptation and Vulnerability Working Group II Contribution to the Intergovernmental Panel on Climate Change Fourth Assessment Report; IPCC: Geneva, Swirtzeland, 2007.

43. Alam, G.M.M.; Alam, K.; Mushtaq, S. Climate change perceptions and local adaptation strategies of hazard-prone rural households in Bangladesh. Clim. Risk Manag. 2017, 17, 52-63. [CrossRef]

44. Elum, Z.A.; Modise, D.M.; Marr, A. Climate Risk Management Farmer's perception of climate change and responsive strategies in three selected provinces of South Africa. Clim. Risk Manag. 2017, 16, 246-257. [CrossRef]

45. Niles, M.T.; Lubell, M.; Haden, V.R. Perceptions and responses to climate policy risks among California farmers. Glob. Environ. Chang. 2013, 23, 1752-1760. [CrossRef]

46. Gordon, A.J.; Morton, L.W.; Hobbs, J. Understanding Farmer Perspectives on Climate Change Adaptation and Mitigation: The Roles of Trust in Sources of Climate Information, Climate Change Beliefs, and Perceived Risk. Environ. Behav. 2015, 47, 205-234.

47. Lang, T.; Rayner, G. Ecological Public Health. The 21st century's big idea. BMJ 2012, 345, 17-20. [CrossRef]

48. David, E.; Elise, H. Climate Change: Perceptions and Discourses of Risk Climate Change: Perceptions and Discourses of Risk. J. Risk Res. 2007, 10, 623-641.

49. UNEP. Avoiding Future Famines: Strengthening the Ecological Foundation of Food Security through Sustainable Food Systems. In A UNEP Synthesis Report; UNEP: Nairobi, Kenya, 2012.

50. Fisher, E.; Jones, J.; von Schomberg, R. (Eds.) Implementing the Precautionary Principle: Perspectives and Prospects. In Implementing the Precautionary Principle; Edward Elgar: Cheltenham, UK; Northampt, MA, USA, 2006; Volume 136, pp. 1-11.

51. Schindler, B.D.E.; Hilborn, R. Prediction, precaution, and policy under global change. Science 2015, 347, 953-954. [CrossRef] [PubMed]

52. Shivakoti, G.; Ullah, R.; Pradhan, U. Challenges of Sustainable Natural Resources Management in Dynamic Asia. In Redefining Diversity and Dynamics of Natural Resources Management in Asia; Elsevier Inc.: Amsterdam, The Netherlands, 2016; Volume 1, pp. 3-12.

53. Thapa, B.; Scott, C.; Wester, P.; Varady, R. Towards characterizing the adaptive capacity of farmer-managed irrigation systems: Learnings from Nepal. Environ. Sustain. 2016, 21, 37-44. [CrossRef]

54. Moench, M. Development in Practice Experiences applying the climate resilience framework: Linking theory with practice. Dev. Pract. 2014, 24, 447-464. [CrossRef]

55. Schipper, E.L.F.; Thomalla, F.; Vulturius, G.; Davis, M.; Johnson, K. Linking disaster risk reduction, climate change and development. Int. J. Disaster Reslience Built Environ. 2016, 7, 216-228. [CrossRef]

56. Mukheibir, P.; Ziervogel, G. Developing a Municipal Adaptation Plan (MAP) for climate change: The city of Cape Town. Environ. Urban. 2007, 19, 143-158. [CrossRef] 
57. Meek, C.L.; Lauren, A.; Varjopuro, R.; Dowsley, M.; Dale, A.T. Adaptive governance and the human dimensions of marine mammal management: Implications for policy in a changing North. Mar. Policy 2011, 35, 466-476. [CrossRef]

58. Termeer, C.; Dewulf, A.; Breeman, G. Governance of Wicked Climate Adaptation Problems. In Climate Change Governance, Climate Change Management; Knieling, J., Walter, L.F., Eds.; Springer: Berlin/Heidelberg, Germany, 2013; pp. 27-39.

59. Baer, P. Adaptation: Who pays Whom? In Fairness in Adaptation to Climate Change; Adger, W.N., Pavoola, J., Huq, S., Mace, M.J., Eds.; MIT Press: Cambridge, MA, USA, 2006; pp. 133-153. ISBN 9780262012270336.

60. Ding, Y.; Peng, J. Impacts of Urbanization of Mountainous Areas on Resources and Environment: Based on Ecological Footprint Model. Sustainability 2018, 10, 765. [CrossRef]

61. Loboguerrero, A.M.; Campbell, B.M.; Cooper, P.J.M.; Hansen, J.W.; Rosenstock, T.; Wollenberg, E. Food and Earth Systems: Priorities for Climate Change Adaptation and Mitigation for Agriculture and Food Systems. Sustainability 2019, 11, 1372. [CrossRef]

62. Pahl-Wostl, C. Transitions towards adaptive management of water facing climate and global change. Water Resour. Manag. 2007, 21, 49-62. [CrossRef]

63. FAO. The Water-Energy-Food Nexus; FAO: Rome, Italy, 2014.

64. Paton, D.; McClure, J. Preparing for Disaster: Building Household and Community Capacity; Charles C Thomas Publisher Ltd.: Springfield, IL, USA, 2013.

65. Spence, A.; Pidgeon, N. Framing and communicating climate change: The effects of distance and outcome frame manipulations. Glob. Environ. Chang. 2010, 20, 656-667. [CrossRef]

66. Volenzo, T.E.; Odiyo, J.O. Ecological public health and participatory planning and assessment dilemmas: The case of water resources management. Int. J. Environ. Res. Public Health 2018, 15, 1635. [CrossRef] [PubMed]

67. Ayers, J.M.; Huq, S. The Value of Linking Mitigation and Adaptation: A Case Study of Bangladesh. Environ. Manag. 2009, 43, 753-764. [CrossRef] [PubMed]

68. Pelling, M.; High, C. Understanding adaptation: What can social capital offer assessments of adaptive capacity? Glob. Environ. Chang. 2005, 15, 308-319. [CrossRef]

69. Mu, D.; Kaplan, T.R.; Dankers, R. Decision making with risk-based weather warnings. Int. J. Disaster Risk Reduct. 2018, 30, 59-73. [CrossRef]

70. Niles, M.T.; Lubell, M.; Brown, M. Agriculture, Ecosystems and Environment. How limiting factors drive agricultural adaptation to climate change. Agric. Ecosyst. Environ. 2015, 200, 178-185. [CrossRef]

71. Jackson, L.; Van Noordwijk, M.; Bengtsson, J.; Foster, W.; Lipper, L.; Pulleman, M.; Said, M.; Snaddon, J.; Vodouhe, R. Biodiversity and agricultural sustainagility: From assessment to adaptive management. Curr. Opin. Environ. Sustain. 2010, 2, 80-87. [CrossRef]

72. Volenzo, T.E.; Odiyo, J.; Obiri, J. Greenhouse gas emissions as sustainability indicators in agricultural sectors ' adaptation to climate change: Policy implications. J. Disaster Risk Stud. 2019, 11, 9. [CrossRef]

73. Walthall, C.L.; Hatfield, J.; Backlund, P.; Lengnick, L.; Marshall, E.; Walsh, M.; Adkins, S.; Aillery, M.; Ainsworth, E.A.; Ammann, C.; et al. Climate Change and Agriculture in the United States: Effects and Adaptation; USDA, Agricultural Research Service and Climate Change Program Office: Washington, DC, USA, 2012.

74. MEA. Ecosystems and Human Well-Being: A Framework for Assessment; Island Press: Washington, DC, USA; Covelo, CA, USA; London, UK, 2003.

75. Parish, E.S.; Herzberger, A.J.; Phifer, C.C.; Dale, V.H. Transatlantic wood pellet trade demonstrates telecoupled benefits. Ecol. Soc. 2018, 23. [CrossRef]

76. Liu, J.; Hull, V.; Batistella, M.; Defries, R.; Dietz, T.; Fu, F.; Hertel, T.W.; Cesar, R.; Lambin, E.; Li, S.; et al. Framing Sustainability in a Telecoupled World. Ecol. Soc. 2013, 18, 26-45. [CrossRef]

77. Adger, W.N. Social Capital, Collective Action, and Adaptation to Climate Change. Econ. Geogr. 2003, 79, 387-404. [CrossRef]

78. Holland, T.; Smit, B. Climate Change and the Wine Industry: Current Research Themes and New Directions. J. Wine Res. 2010, 21, 125-136. [CrossRef]

79. Rogers, M.B.; Amlôt, R.; Rubin, G.J.; Wessely, S.; Krieger, K. Mediating the social and psychological impacts of terrorist attacks: The role of risk perception and risk communication. Int. Rev. Psychiatry 2007, 19, 279-288. [CrossRef] [PubMed] 
80. Easterling, W.; Aggarwal, P.; Batima, P.; Brander, K.; Erda, L.; Howden, M.; Kirilenko, A.; Morton, J.; Soussana, J.F.; Schmidhuber, J.; et al. Food, fibre and forest products. In Climate Change 2007: Impacts, Adaptation and Vulnerability. Contribution of Working Group II to the Fourth Assessment Report of the Intergovernmental Panel on Climate Change; Parry, M.L., Canziani, O.F., Palutikof, J.P., van der Linden, P.J., Hanson, C.E., Eds.; Cambridge University Press: Cambridge, UK, 2007; pp. 273-313.

81. Volenzo, T.E.; Odiyo, J.O. Linking risk communication and sustainable climate change action: A conceptual framework. J. Disaster Risk Stud. 2019, 11,1-11. [CrossRef]

82. Hitayezu, P.; Wale, E.; Ortmann, G. Climate Risk Management Assessing farmers' perceptions about climate change: A double-hurdle approach. Clim. Risk Manag. 2017, 17, 123-138. [CrossRef]

83. IPCC. Managing the Risks of Extreme Events and Disasters to Advance Climate Change Adaptation. A Special Report of Working Groups I and II of the Intergovernmental Panel on Climate Change; Cambridge University Press: Cambridge, UK, 2012.

84. Matyas, D.; Pelling, M. Positioning resilience for 2015: The role of resistance, incremental adjustment and transformation in disaster risk management policy. Disasters 2015, 39, s1-s18. [CrossRef]

85. Pidgeon, N.; Rogers-Hayden, T. Opening up nanotechnology dialogue with the publics: Risk communication or "upstream engagement"? Health Risk Soc. 2007, 9, 191-210. [CrossRef]

86. Jihan, N.; Mcshane, P. Landscape and Urban Planning Ecosystem services management: An evaluation of green adaptations for urban development in Dhaka, Bangladesh. Landsc. Urban Plan. 2018, 173, 23-32.

87. Becker, J.S.; Paton, D.; Johnston, D.M.; Ronan, K.R.; McClure, J. The role of prior experience in informing and motivating earthquake preparedness. Int. J. Disaster Risk Reduct. 2017, 22, 179-193. [CrossRef]

88. Dietz, T.; Dan, A.; Shwom, R. Support for Climate Change Policy: Social Psychological and Social Structural Influences. Rural Sociol. 2007, 72, 185-214. [CrossRef]

89. Aldunce, P.; Beilin, R.; Howden, M.; Handmer, J. Resilience for disaster risk management in a changing climate: Practitioners' frames and practices. Glob. Environ. Chang. 2015, 30, 1-11. [CrossRef]

90. Ravikumar, P.; Somashekar, R.K. Assessment and Modelling of Groundwater Quality Data and Evaluation of Their Corrosiveness and Scaling Potential Using Environmetric Methods in Bangalore South Taluk, Karnataka state, India. Water Resour. 2012, 39, 446-473. [CrossRef]

91. Asfaw, E.; Suryabhagavan, K.V.; Argaw, M. Soil salinity modeling and mapping using remote sensing and GIS: The case of Wonji sugar cane irrigation farm, Ethiopia. J. Saudi Soc. Agric. Sci. 2018, 17, 250-258. [CrossRef]

92. Elhag, M. Evaluation of Different Soil Salinity Mapping Using Remote Sensing Techniques in Arid Ecosystems, Saudi Arabia. J. Sens. 2016, 2016, 7596175. [CrossRef]

93. van Rensburg, L.; de Clercq, W.; Barnard, J.; Preez Du, C. Salinity guidelines for irrigation: Case studies from Water Research Commission projects along the Lower Vaal, Riet, Berg and Breede Rivers. Water SA 2011, 37, 739-750. [CrossRef]

94. Zewdu, S.; Suryabhagavan, K.V.; Balakrishnan, M. Geo-spatial approach for soil salinity mapping in Sego Irrigation Farm, South Ethiopia. J. Saudi Soc. Agric. Sci. 2017, 16, 16-24. [CrossRef]

95. Rietz, D.N.; Haynes, R.J. Effects of irrigation-induced salinity and sodicity on soil microbial activity. Soil Biol. Biochem. 2003, 35, 845-854. [CrossRef]

96. Wei, Q.; Xu, J.; Liao, L.; Li, Y.; Wang, H.; Rahim, S.F. Water Salinity Should Be Reduced for Irrigation to Minimize Its Risk of Increased Soil $\mathrm{N}_{2} \mathrm{O}$ Emissions. Int. J. Environ. Res. Public Health 2018, 15, 2114. [CrossRef]

97. Gorji, T.; Sertel, E.; Tanik, A. Monitoring soil salinity via remote sensing technology under data scarce conditions: A case study from Turkey. Ecol. Indic. 2017, 74, 384-391. [CrossRef]

98. Odiyo, J.O.; Makungo, R.; Muhlarhi, T.G. The impacts of geochemistry and agricultural activities on groundwater quality in the soutpansberg fractured aquifers. WIT Trans. Ecol. Environ. 2014, 182, 121-132.

99. Turner, B.L.; Kasperson, R.E.; Matsone, P.A.; McCarthy, J.J.; Corell, R.W.; Christensene, L.; Eckley, N.; Kasperson, J.X.; Amy, L.; Marybeth, A.L.; et al. A framework for vulnerability analysis in sustainability science. Proc. Natl. Acad. Sci. USA 2003, 100, 8074-8079. [CrossRef]

100. Bhattacharyya, R.; Ghosh, B.; Mishra, P.; Mandal, B.; Rao, C.S.; Sarkar, D.; Das, K.; Anil, K.S.; Lalitha, M.; Hati, K.; et al. Soil Degradation in India: Challenges and Potential Solutions. Sustainability 2015, 7, 3528-3570. [CrossRef] 
101. Pelling, M.; Özerdem, A.; Barakat, S. The macro-economic impact of disasters. Prog. Dev. Stud. 2002, 2, 283-305. [CrossRef]

102. Zamani, G.H.; Gorgievski-Duijvesteijn, M.; Zarafshani, K. Coping with Drought: Towards a Multilevel Understanding Based on Conservation of Resources Theory. Hum. Ecol. 2006, 34, 677-692. [CrossRef]

103. G.O.K. Agricultural Sector Transformation and Gowth Strategy 2019-2029; Government printer: Nairobi, Kenya, 2019.

104. G.O.K. Climate Change Action Plan 2018-2022; Ministry of Environment and Forestry: Nairobi, Kenya, 2018.

105. Republic of Kenya. Environmental Management and Co-Ordination (Amendment) Act No. 8 of 1999 (Revised, 2012); Kenya Law press: Nairobi, Kenya, 2015; p. 81.

106. Republic of Kenya. Climate Change Act No. 11 of 2016; Government printer: Nairobi, Kenya, 2016; pp. 1-15.

107. KNBS. Counting Our People for Implementation of Vision 2030; Government Printer: Nairobi, Kenya, 2009.

108. Jaetzold, R.; Schmidt, H.; Hornetz, B.; Shisanya, C. Farm Management Handbook of Kenya Vol 11-Natural Condtions and Farm Management Information, 2nd ed.; Part II/A1(western Kenya) and Part II/CI(Eastern Province); Ministry of Agriculture, Kenya/GTZ: Nairobi, Kenya, 2011; Volume II.

109. Republic of Kenya. Kakamega County Integrated Development Plan 2018-2022; County Government of Kakamega: Kakamega, Kenya, 2019.

110. FAO. Agro-Ecological Zoning Guidelines: FAO Soils Bulletin No. 73; Land and Water Development Division, FAO: Rome, Italy, 1996.

111. Republic of Kenya. Machakos County Integrated Development Plan, 2015; County Government of Machakos: Machakos, Kenya, 2015.

112. Chen, T.; Liu, X.; Li, X.; Zhao, K.; Zhang, J.; Xu, J.; Shi, J.; Dahlgren, A. Heavy metal sources identification and sampling uncertainty analysis in a field-scale vegetable soil of Hangzhou, China. Environ. Pollut. 2009, 157, 1003-1010. [CrossRef]

113. Fisher, A.; Laing, J.; Stoeckel, J. A Handbook for Family Planning Operations Research Designs; The Population Council: New York, NY, USA, 1983.

114. Hosmer, D.W.; Lemeshow, S. Applied Logistic Regression, 1st ed.; John Wiley and Sons: New York, NY, USA, 2000.

115. Helgeson, J.F.; Dietz, S.; Hochrainer-stigler, S. Vulnerability to Weather Disasters: The Choice of Coping Strategies in Rural Uganda. Ecol. Soc. 2013, 18, 2-15. [CrossRef]

116. Richards, L.A. Diagnosis and Improvement of Saline and Alkali Soils; No. Agricultural Handbook No.60; US Department of Agriculture: Washington, DC, USA, 1954.

117. Huffman, W.E. Human Capital: Education and Agriculture. In Handbook of Agricultural Economics; Rausser, G.C., Gardner, B.L., Eds.; Elsevier: New York, NY, USA, 2001; pp. 333-381.

118. Mojtahedi, M.; Oo, B.L. Critical attributes for proactive engagement of stakeholders in disaster risk management. Int. J. Disaster Risk Reduct. 2017, 21, 35-43. [CrossRef]

119. Evans, H.; Dyll, L.; Teer-tomaselli, R. Communicating Climate Change: Theories and Perspectives. In Handbook of Climate Change Communication: Climate Change Management; Leal Filho, W., Manolas, E., Azul, A.M., Azeiteiro, U.M., McGhie, H., Eds.; Springler AG: Berlin, Germany, 2018; Volume 1, pp. 107-122.

120. Koundouri, P.; Nauges, C.; Tzouvelekas, V. Technology Adoption under Production Uncertainty: Theory and Application to Irrigation Technology. Am. J. Agric. Econ. 2019, 88, 657-670. [CrossRef]

121. Shapira, S.; Aharonson-daniel, L.; Bar-dayan, Y. Anticipated behavioral response patterns to an earthquake: The role of personal and household characteristics, risk perception, previous experience and preparedness. Int. J. Disaster Risk Reduct. 2018, 31, 1-8. [CrossRef]

122. Bailey, B.K.W. The Fundamentals of Forward Contracting, Hedging, and Options for Dairy Producers in the Northeast; Penn State University: State College, PA, USA, 2001.

123. Maredia, M.K.; Minde, I.J. Technology, Profitability and agricultural Transformation: Concepts, Evidence and Policy implications. In Perspectives on Agricultural Transformation. A View from Africa; Jayne, T.S., Minde, P., Argwings-Kodhek, G.G., Eds.; Nova Science Publishers Inc.: New York, NY, USA, 2002; pp. 83-116. 
124. Ullah, R.; Shivakoti, G.P.; Zulfiqar, F.; Kamran, M.A. Farm risks and uncertainties: Sources, impacts and management. Outlook Agric. 2016, 45, 199-205. [CrossRef]

125. Howden, S.; Jean-Fancois, S.; Tubiello, F.; Chhetri, N.; Dunlop, M.; Meinke, H. Adapting agriculture to climate change. Proc. Natl. Acad. Sci. USA 2007, 104, 19691-19696. [CrossRef]

(C) 2019 by the authors. Licensee MDPI, Basel, Switzerland. This article is an open access article distributed under the terms and conditions of the Creative Commons Attribution (CC BY) license (http://creativecommons.org/licenses/by/4.0/). 